\title{
Investigating the Moderating role of Organizational Identity on the Relationship between Managerial Compensation and Earnings Manipulation
}

\author{
Ahmad Abdollahi1 \\ Assistant Professor of Accounting, Golestan Institute of Higher Education, \\ Gorgan, Iran(ahmabdollahi@gmail.com) \\ Fatemeh Riahi \\ MA in Accounting, Golestan Institute of Higher Education, Gorgan, \\ Iran.(fateme.riahi@yahoo.com) \\ Yasser Rezaei Pitenoei* \\ Assistant Professor of Accounting, University of Guilan, Rasht, \\ Iran.(Corresponding Author), rezaei.yasser@gmail.com
}

\begin{abstract}
:
The adoption of compensation contracts to motivate executives to exert effective and conducive efforts has raised worries about the likelihood of earnings manipulation by management. On the other hand, recent studies show that organizational identity (OI) can have a great impact on motivating managers to exhibit their optimal performance and reduce agency costs as managers' performance towards the benefits of their firms could enhance their desirability. Therefore, the main purpose of this study is to investigate the relationship between managerial compensation and earnings manipulation with focus on the moderating effect of organizational identity on this relationship. The statistical population of the research includes financial managers of 76 companies in five industries including automobile and automobile parts manufacturing, machinery, electrical machinery and equipment, basic metals and metal products manufacturing listed on the Tehran Stock Exchange in 2018. In pursuit of this goal, standard questionnaires were used to collect the research data following the study of Abernethy et al (2017) and a questionnaire was sent to each company. Finally, 68 companies answered the questionnaires and were included in statistical analysis. The research hypotheses are tested using structural equation method and PLS software. Having ensured the good-fitness of the structural and measurement models, the results reveal that managerial compensation have a positive effect on earnings manipulation and organizational identity has a negative effect on earnings manipulation. Also, organizational identity
\end{abstract}


Semiannually journal of Value \& Behavioral Accounting dot 10.52547/aapc.5.10.230

moderates the positive effect between compensation and earnings manipulation and undermines the severity of the effect. Research findings can help investors, capital market regulators and other accounting information users understand the impact of organizational identity on capital market prosperity and guide their decision making.

Keywords:Compensation Contract, Earnings Manipulation, Organizational Identity.

\section{Copyrights @) (1)}

This license only allowing others to download your works and share them with others as long as they credit you, but they can't change them in any way or use them commercial. 


\section{مقاله يُوروشى}

دو فصلنامه حسابدارى ارزشى و رفتارى- سال ينجم، شماره دهم، پإييز و زمستان، صفحه ا •r-•rr

\section{بررسى نقش تعديل كنندىى هويت سازمافى بر رابطه بين پاداش مليران مالى و دستكارى سود

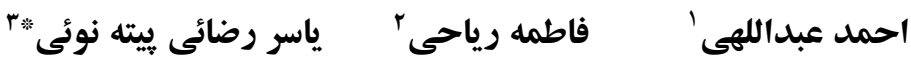 \\ تاريخ هذيرش: \\ تاريخ دريافت:}

جكيده

استفاده از قراردادهاى باداش به منظور ايجاد انگَيزه براى انجام تلاش مؤثر و سودمند باعث

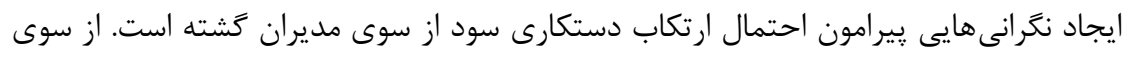

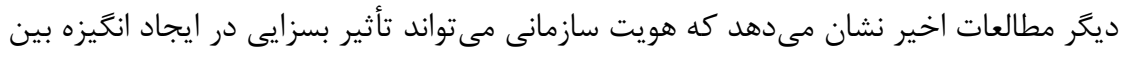

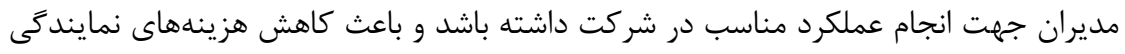

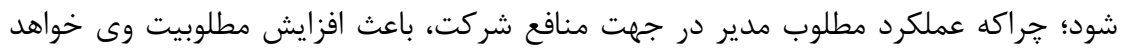

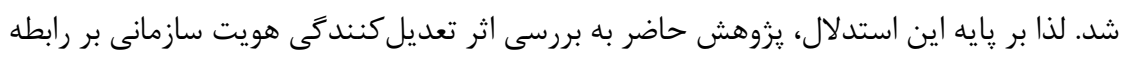

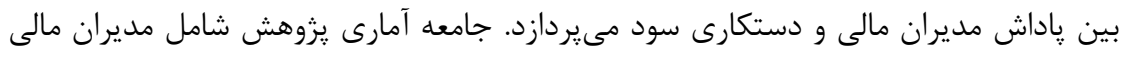

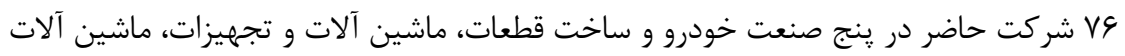

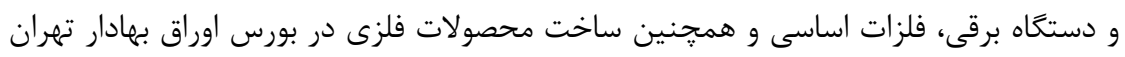

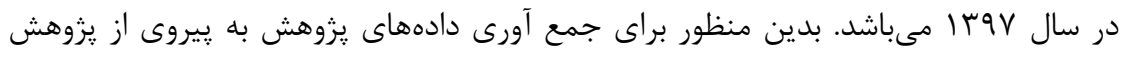

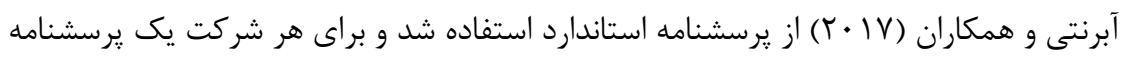

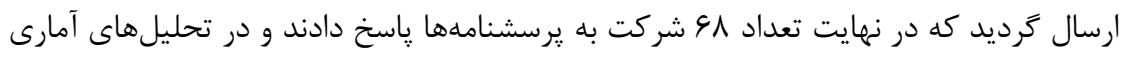

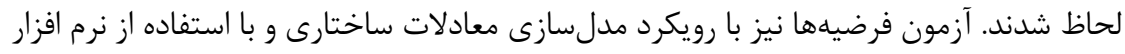

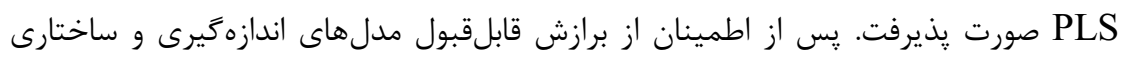

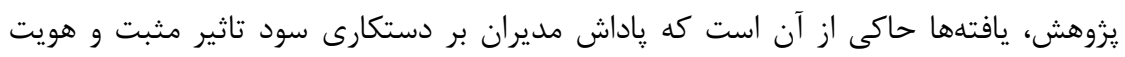

'استاديار حسابدارى، موسسه آموزش عالى كلستان، كر كان، ايران(ahmabdollahi@gmail.com)

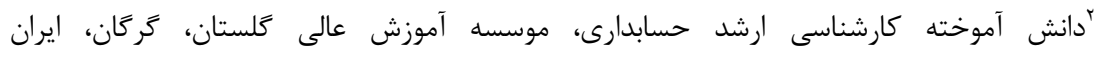
(fateme.riahi@yahoo.com) "استاديار حسابدارى، دانشكدة ادبيات و علوم انسانى، دانشكاه گيلان، رشت، ايران (نويسنده مسئول)، rezaei.yasser@gmail.com 
سازمانى بر دستكارى سود اثر منفى دارد. همجنين هويت سازمانى، اثر مثبت بين پاداداش و

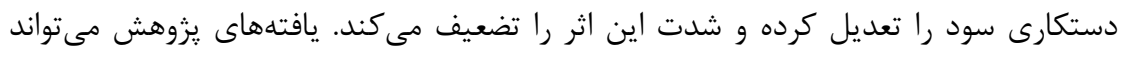

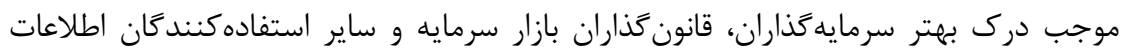

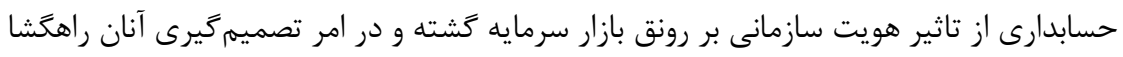

كليدوازه ها: پاداش مديران، دستكارى سود، هويت سازمانى.. 


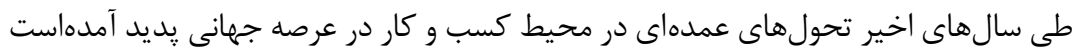

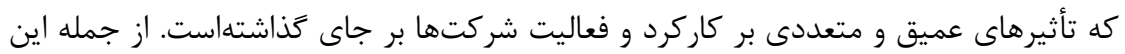
تحولها مى توان به جدايى بيش از پيش مديش

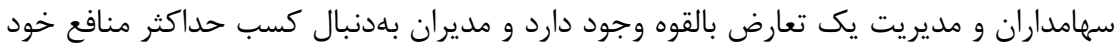

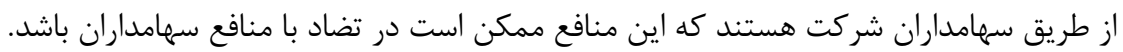

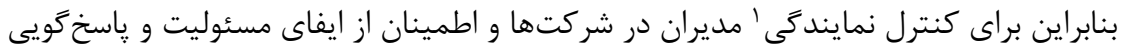

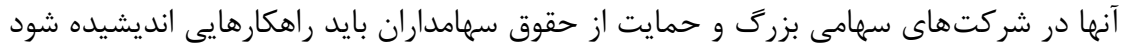

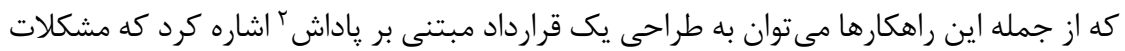

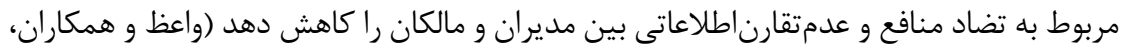

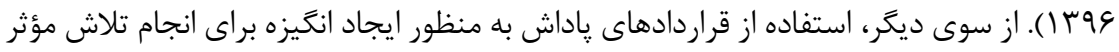

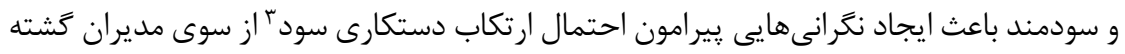

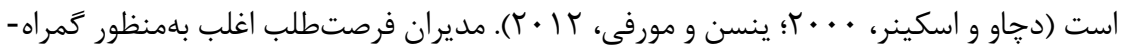
ساختن سهامداران نسبت به عملكرد اقتصادى واقعى شركت، سود را مديريت مى كنند؛ در بسيارى

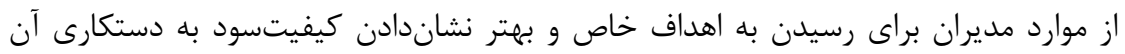

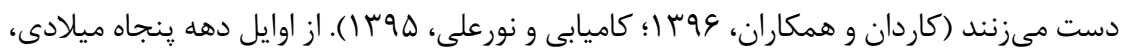

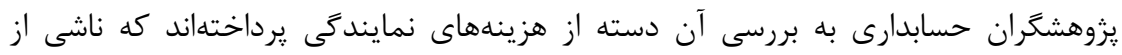

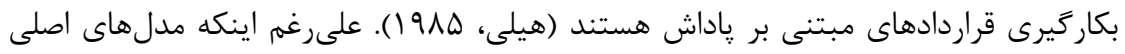

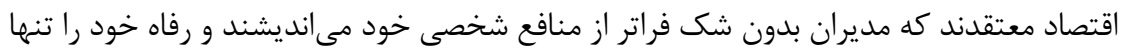

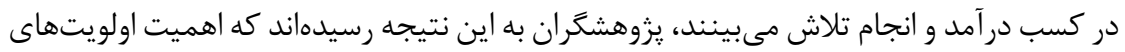

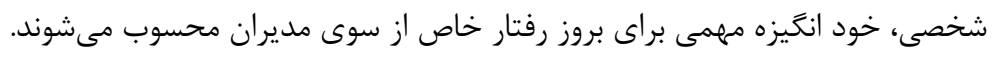

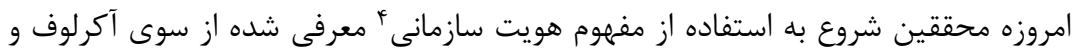

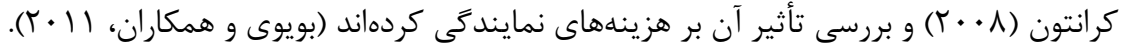

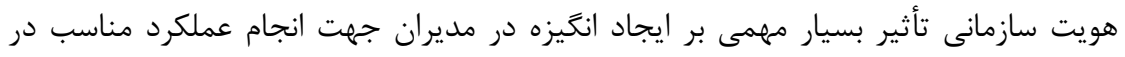

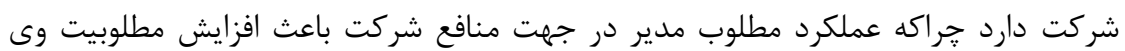

${ }^{1}$ Agency

${ }^{2}$ Compensation

${ }^{3}$ Earnings manipulation

${ }^{4}$ Organizational identity. 
خواهد شد. آشنايى با بنيان هاى نظرى هويت سازمانى كمك زيادى به درك كار ايى مفهوم مذكور

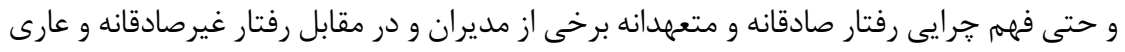

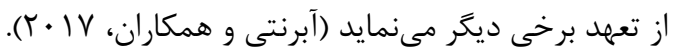

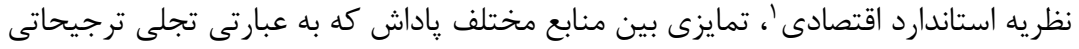

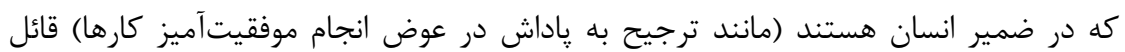

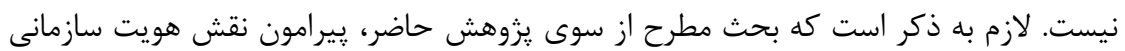

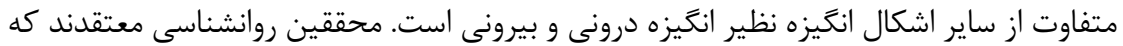

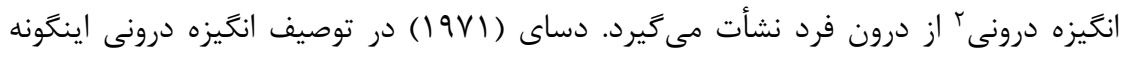

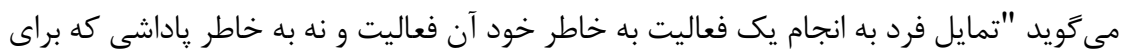

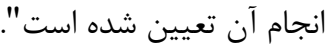
تفاوت هويت سازمانى در اين است كه افراد داراى هويت سازمانى بالاتر، لزوما از انجام

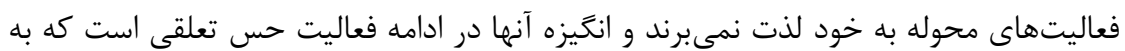

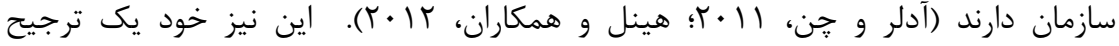

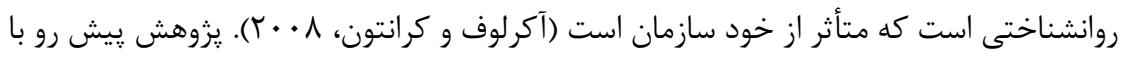

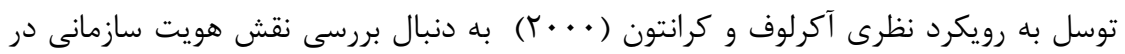
كاهش انتخابهاى فرصتطلبانه كزارشكرى است و درصدد است تا روشن سازد كه كه آيا هويت

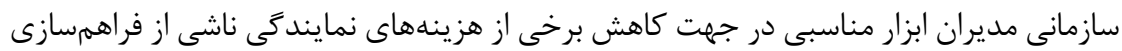

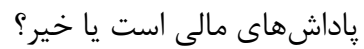

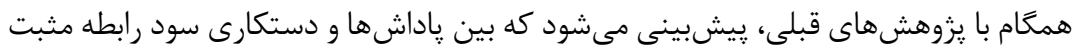

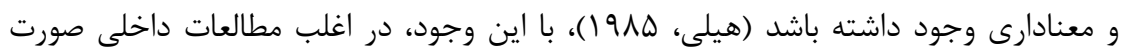

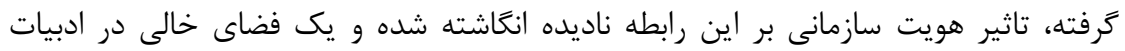

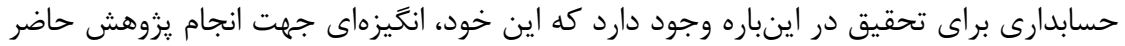

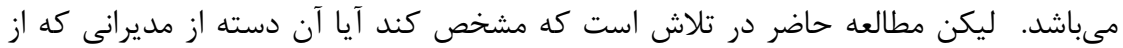

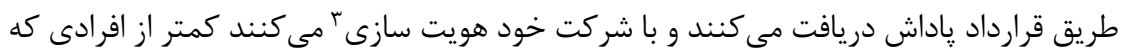

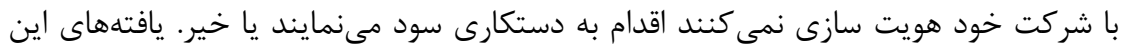

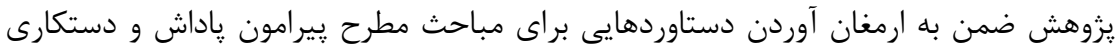

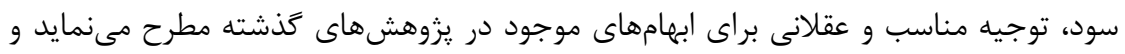

${ }^{1}$ Standard economic theory

${ }^{2}$ Internal motivation

${ }^{3}$ Identification 
زمينه لازم را براى مطالعه تبيينهاى رفتارى در كنار ارائه توجيههاى عقلانى سنتى اقتصادى و

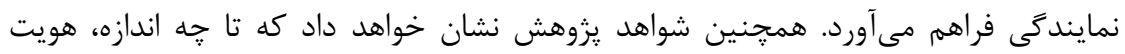

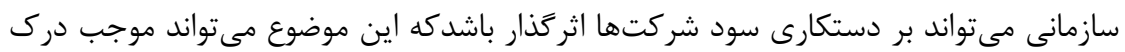

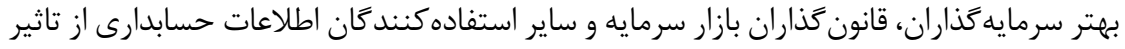

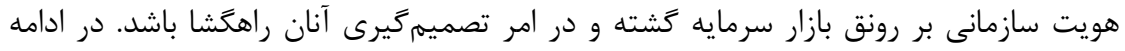

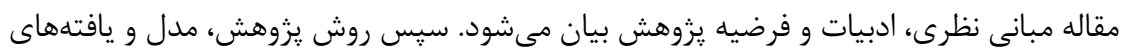

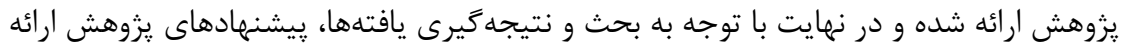

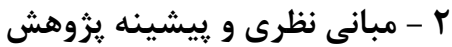 • (ياداش و دستكارى سود}

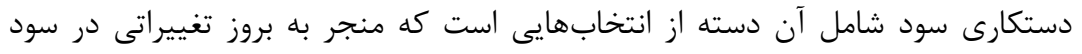

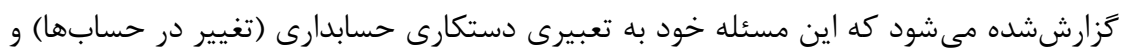

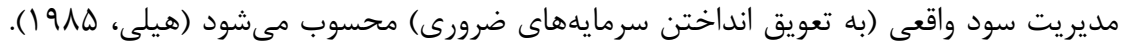

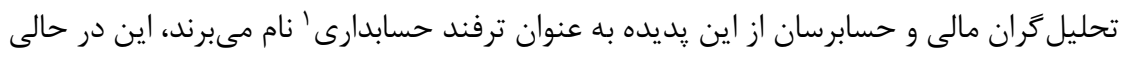

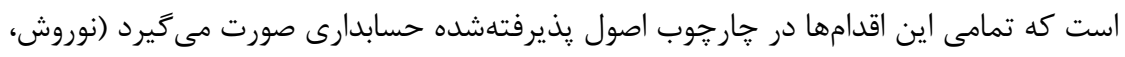

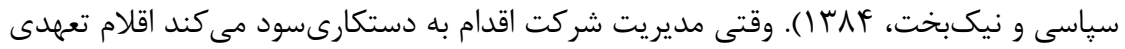

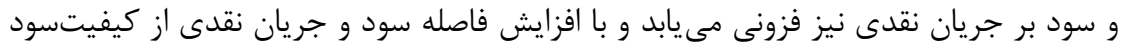

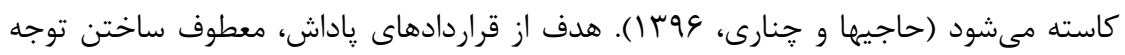

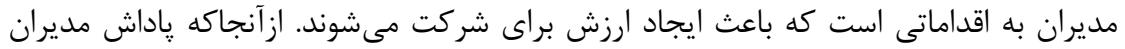

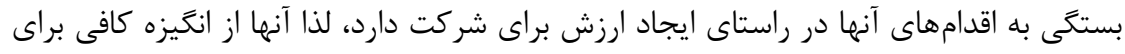

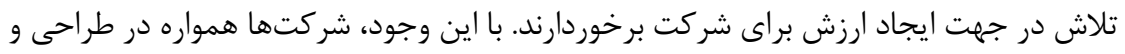

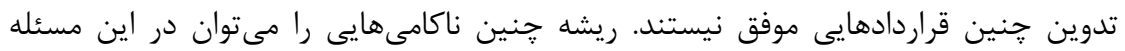

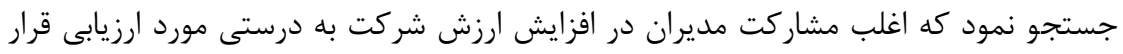

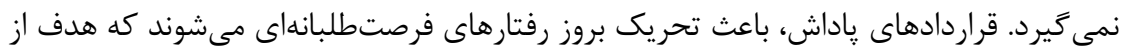

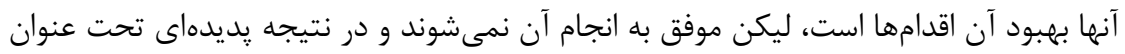

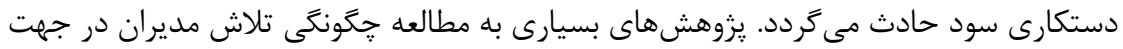

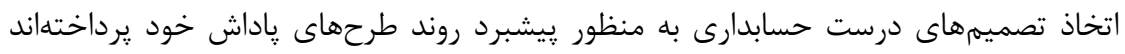

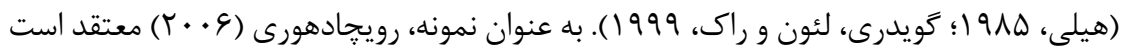

${ }^{1}$ Accounting trick 
كه مديران با اعمال تخفيفاتى بر روى قيمتها به دنبال افزايش درآمد شركت هستند و از سوى ديخر با كاهش هزينههاى اختيارى باعث بهبود عملكرد شركت مي شيوند.

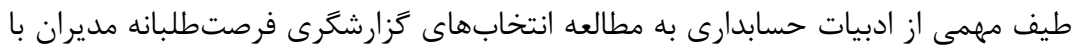
عنايت به اين مطلب يرداختهاند كه مديران با استفاده از اختيارات خود در ززارشگرى، اقدام به مانه

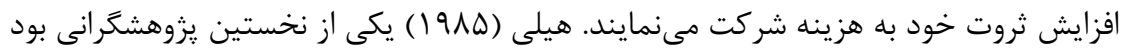

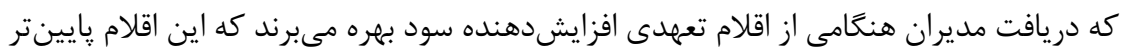
از حد آستانه و يا بالاى حد طرح ياداش باشند، درحاليكه مديران زمانى از اقلام تعهدى

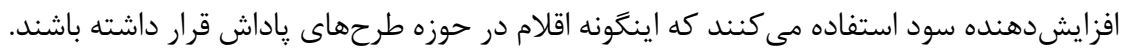

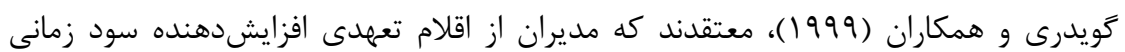
استفاده مى كنند كه آن اقلام تعهدى در محدوده طرح تشويقى قرار بخيرند. مديران مالى، نه تنها مدير هستند بلكه از تحصيلات رسمى در حوزه حسابدارى برخوردارند و لذا از دانش عملى منى

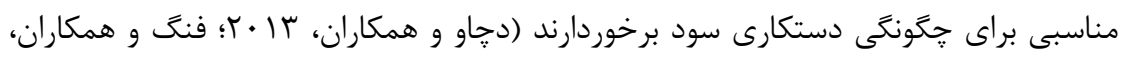

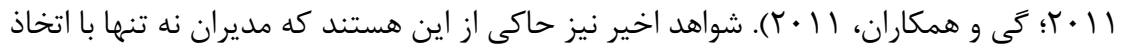
انتخابهاى فرصتطلبانه گزارشگَى درصدد به حداكثررساندن ميزان گِاداش سالانه خود هستند، بلكه اين كار را واكنشى به ياداشهاى مبتنى بر سرمايه قلمداد مى كنـند. نمونههاى متعددى از يُيامدهاى نامطلوب اينگونه رفتارها براى شركت وجود دارد. به عنوان مثال، بركسترسر و فيلييون

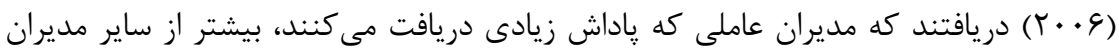

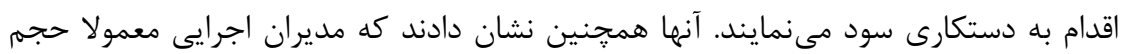
بالايى از سهام را در سالهايى كه اقلام تعهدى بخش وسيعى از سود گزارش شده شركت را

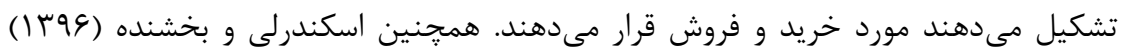

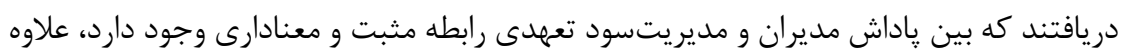
بر اين آنها نشان دادند مديران شركتها با فرصت رشد يايينتر انخيزه بالاترى براى مديريتسود

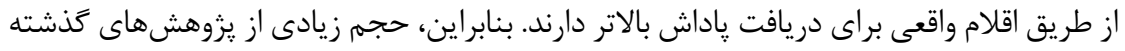

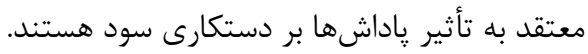

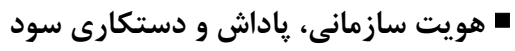
هويت ' يك وازه مبهم و لغزنده است كه به خصو خصوص در در سال هاى اخير در بسيارى از زمينههاى مختلف و براى مقاصد گوناگون مورد استفاده واقع شدهاست، هويت يعنى وجه اختصاصى هر فرد يا گروه، وجه اختصاصى كه در فرد يا گروهى است و در هيج انسان يا گروهى ديخر نيست

${ }^{1}$ Identity 
(عبداللهى، Vq I (). هويت را در يك طبقهبدى كلى مى توان به دو نوع فردى و جمعى (اجتماعى)

$$
\text { تقسيم كرد. }
$$

هويت سازمانى ريشه در نظريه هويت اجتماعى دارد و به ميزان درهمتنيدكى هويت يك فرد با هويت سازمان متبوع وى اتلاق مى

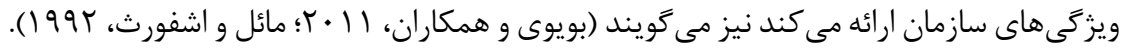

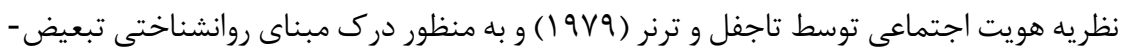

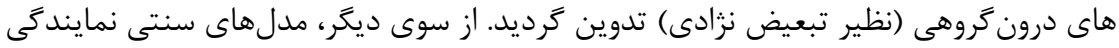

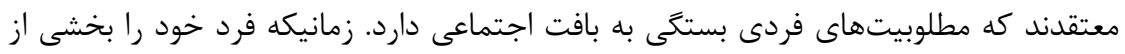

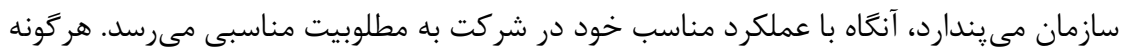

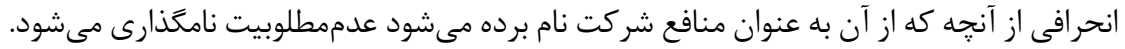

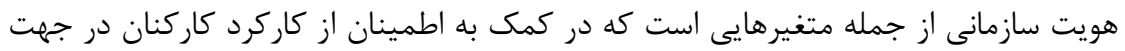

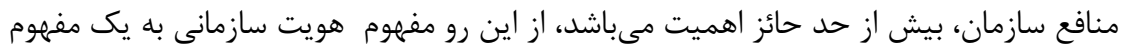

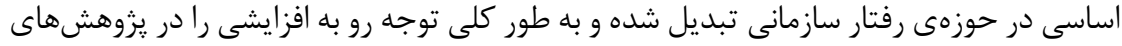

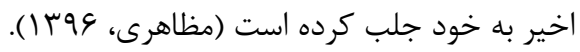

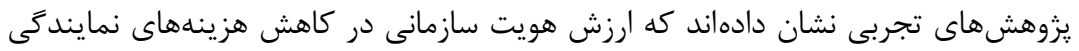

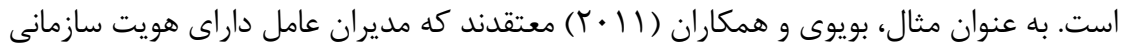

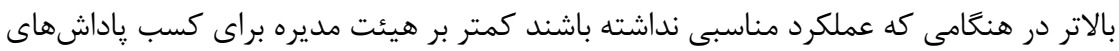

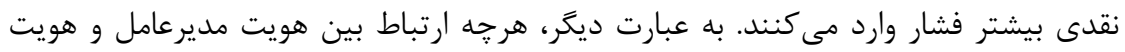

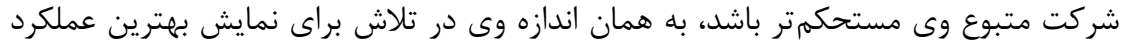

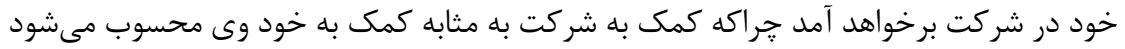

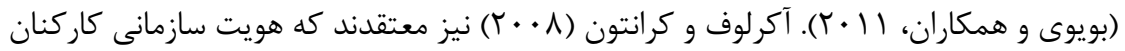

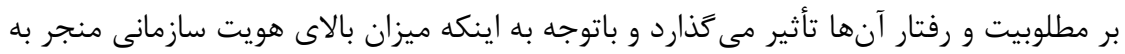

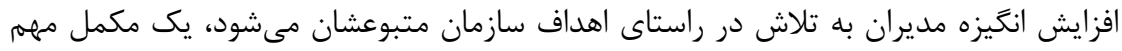

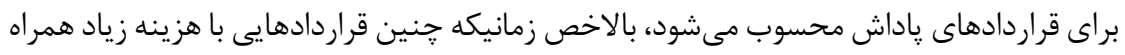

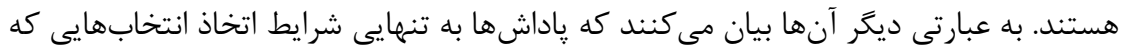
باعث ايجاد ارزش براى شركت شوند را براى مديران فراهم نمى سازند. مطالعه حاضر نيز بر نار نقش

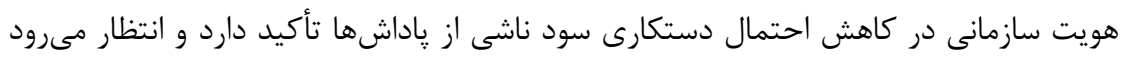

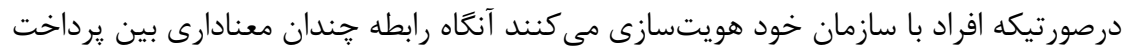

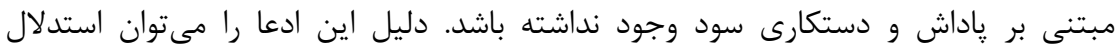

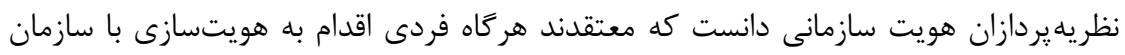


خود نمايد، آنغاه طورى رفتار خواهد نمود كه عملكرد وى بيشترين انتفاع را براى سازمان داشته

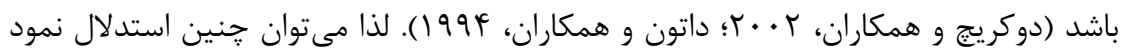

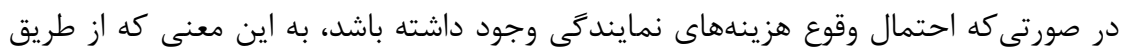

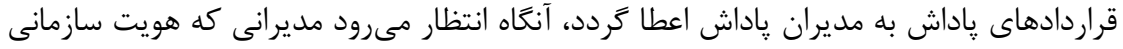

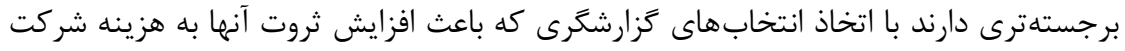

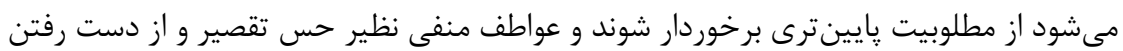

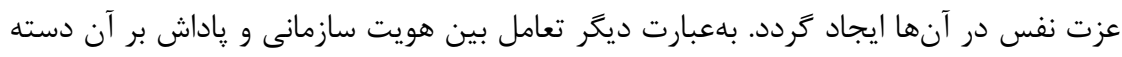

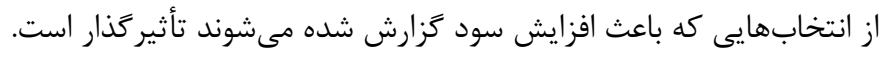

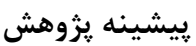

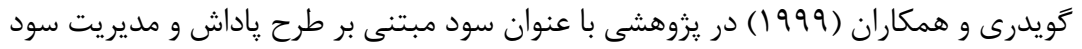

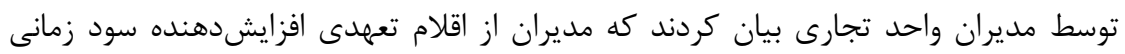

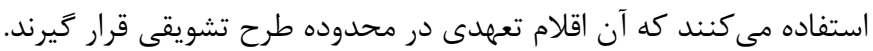

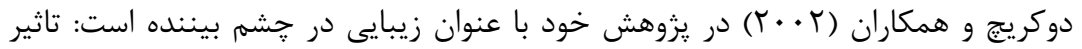

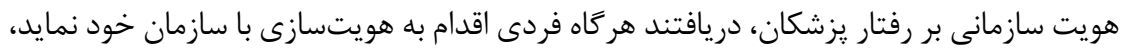

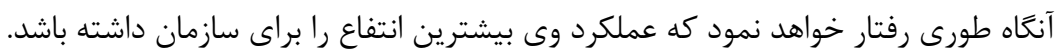

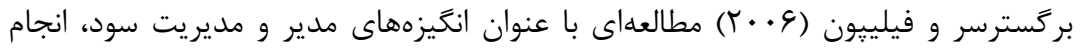

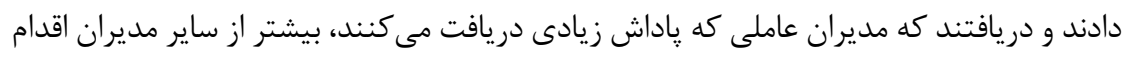
به دآكارى سود مينمايند.

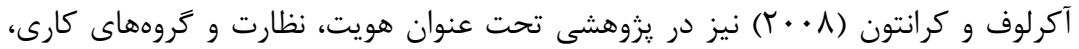

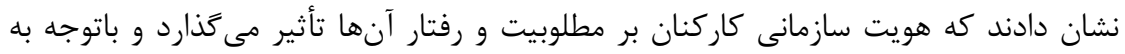

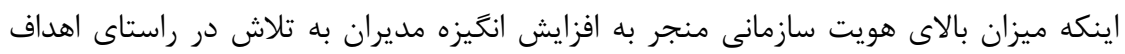

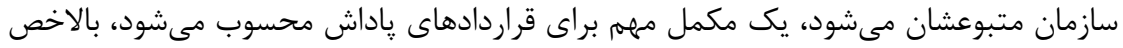

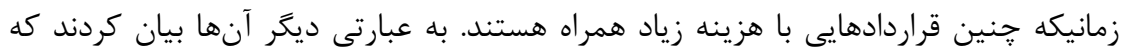

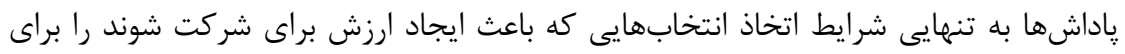

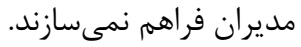

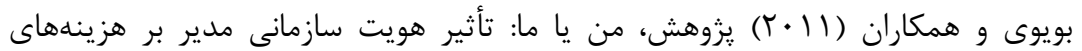

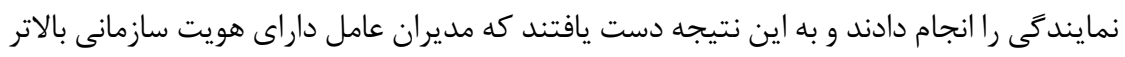
در هنخامى كه عملكرد مناسبى نداشته باشند كمتر بر هيئت مديره براى كسب پِاداشهای

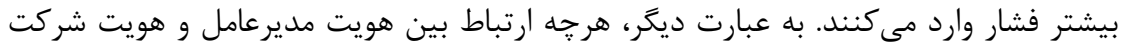


$r+q$ عبدالهى و همكاران، بررسى نقش تعديل كنندَّى هويت سازمانى بر رابطه بين پاداش..

متبوع وى مستحكمتر باشد، به همان اندازه وى در تلاش براى نمايش بهترين عملكرد خود در

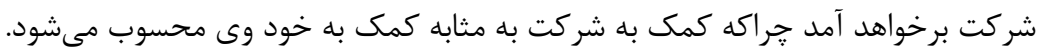

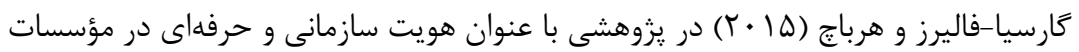
حسابرسى بر اساس رويكرد مؤثر، دريافتند كه هويت سازمانى با تجربيات فرد در مؤسسه رابطه هراجه

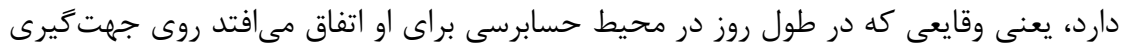

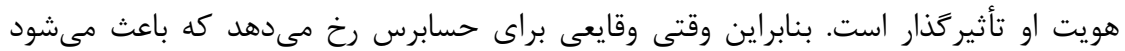

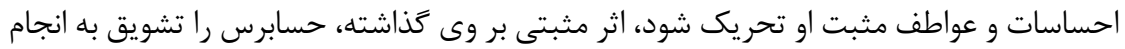
كار در جهت اهداف مؤسسه مى كند.

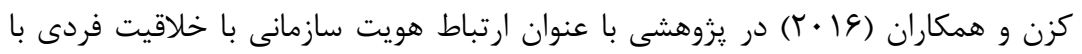

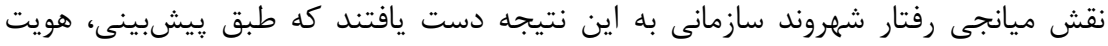

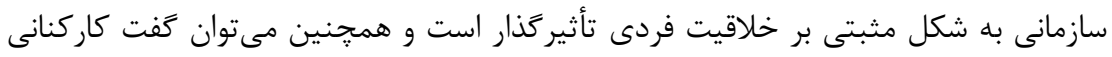

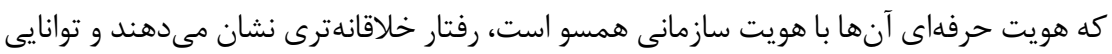

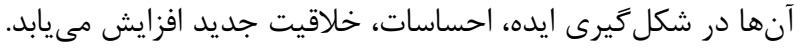

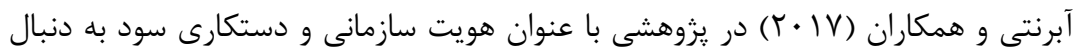

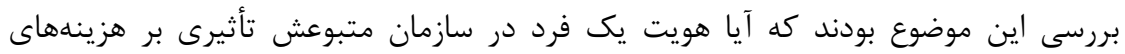

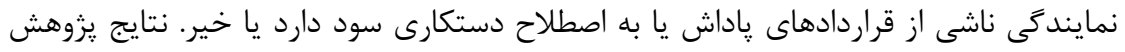

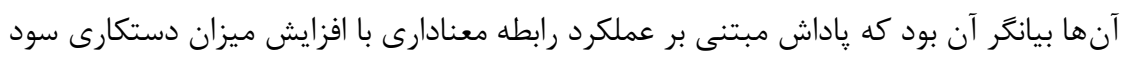

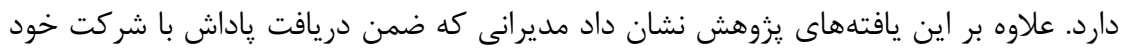

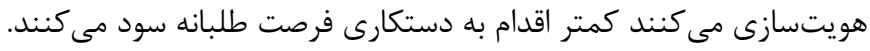

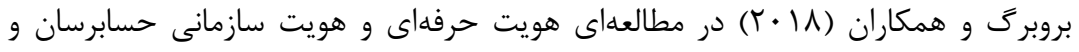

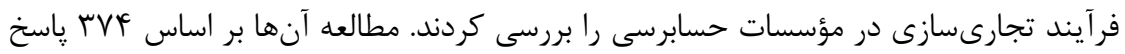

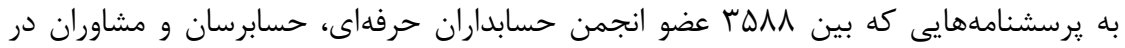

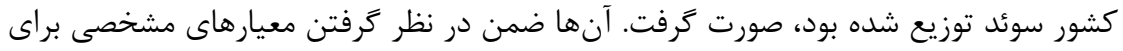

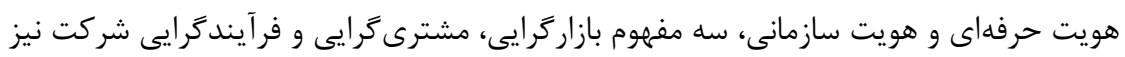

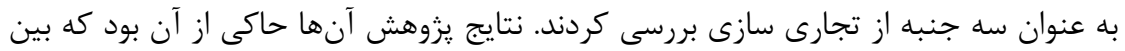

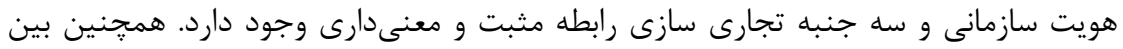

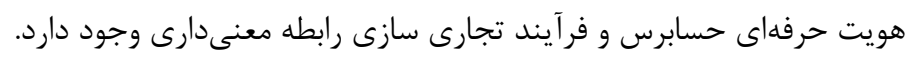

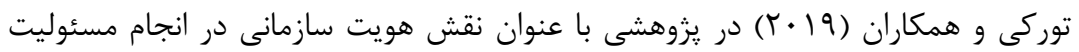

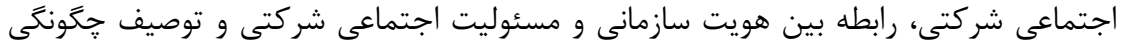

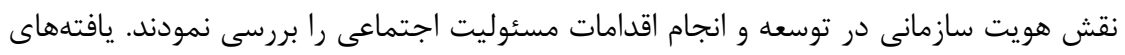


تجربى يزوهش حاصل از انجام مصاحبه با مديران اجرايى ارشد در شركتهاى انگليسى بيان

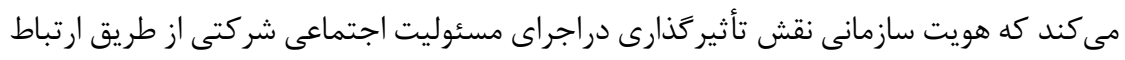

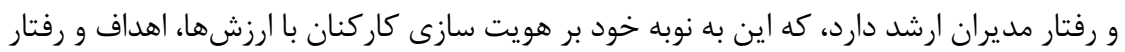

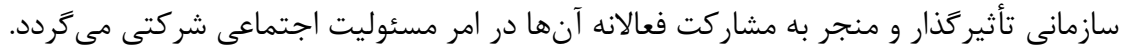

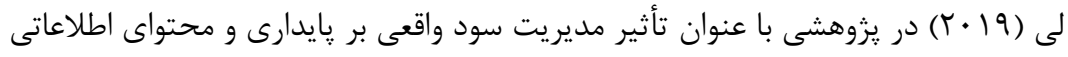

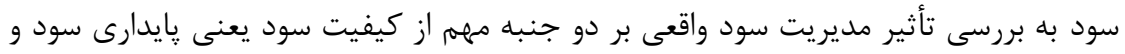

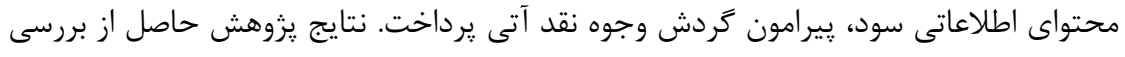

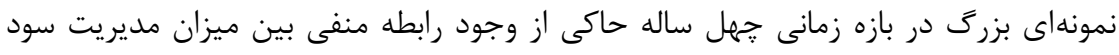

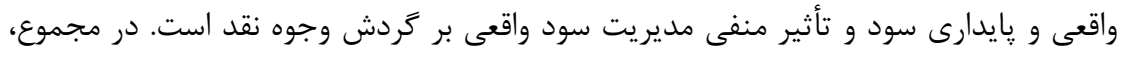

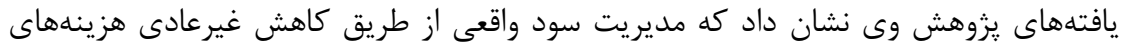

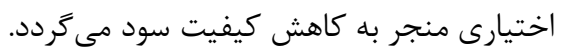

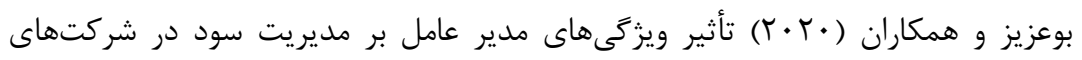

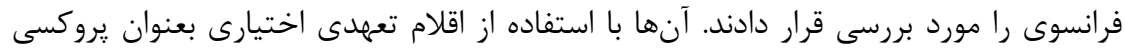

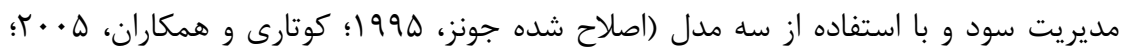

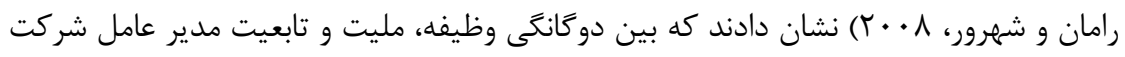

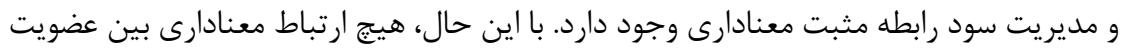
در هيئت مديره و جرخش مدير عامل با مديريت سود وجود ردون ندارد.

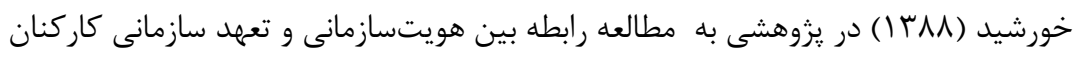

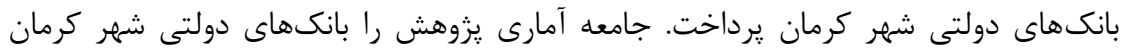

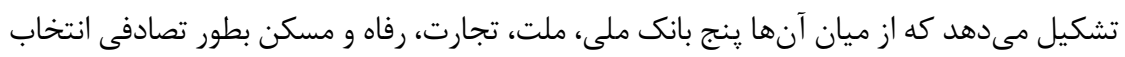

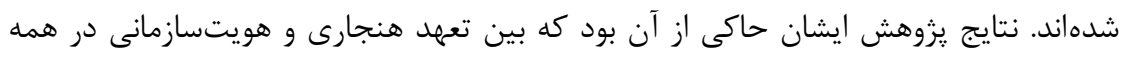

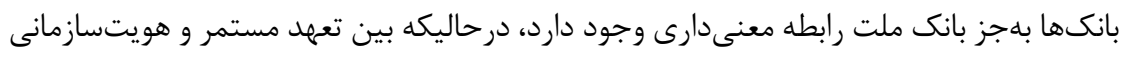

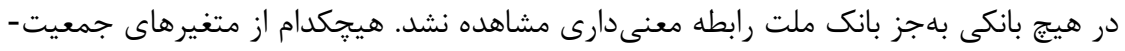

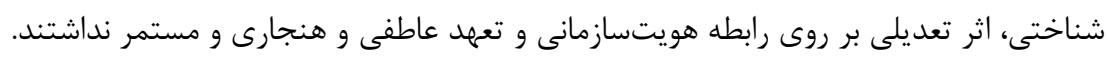

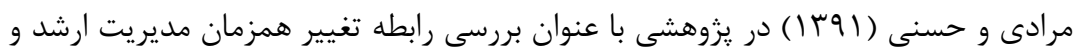

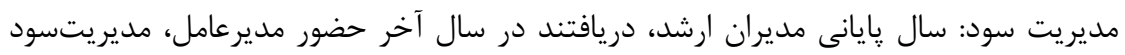

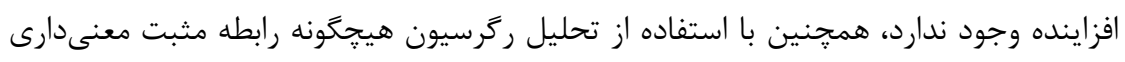

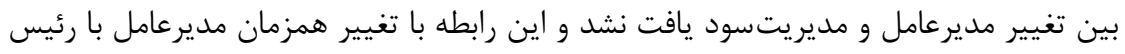

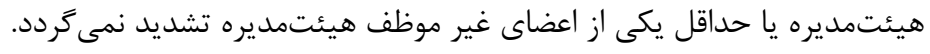




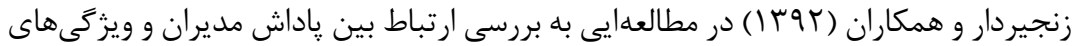

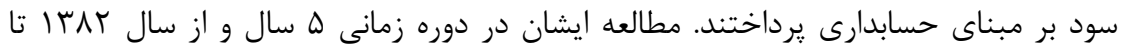

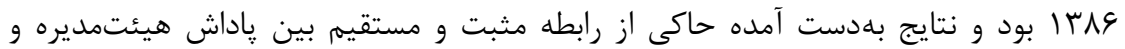

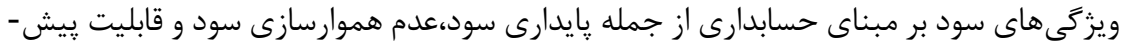
بينى سود مى باشد. همجنين مشخص شد كه بين ياداش مديران و كيفيت اقلام تعهلى درى در بازار سرمايه ايران رابطه وجود ندارد.

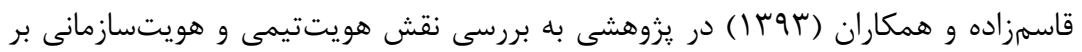

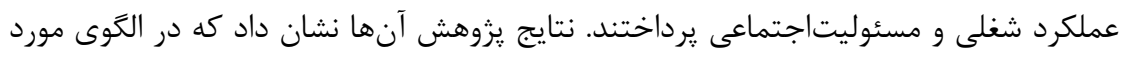

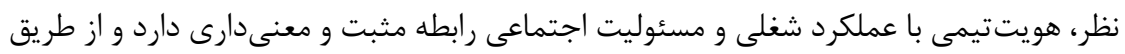

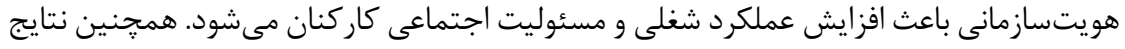

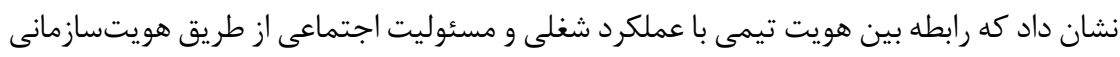
قابل تبيين است.

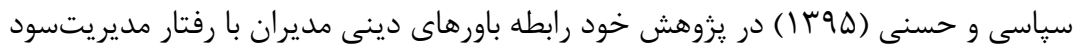

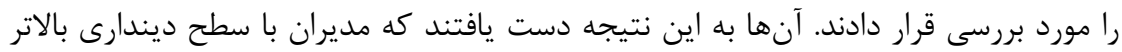

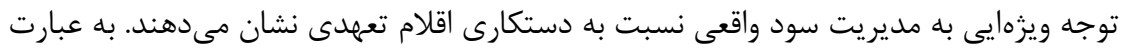

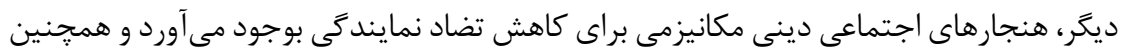

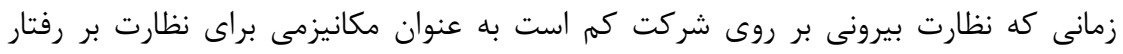

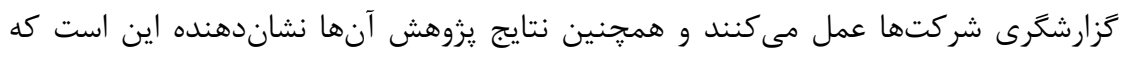

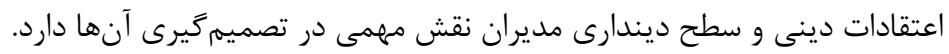

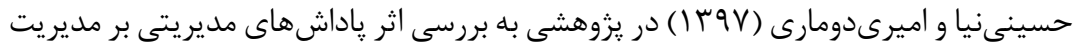

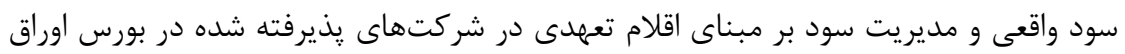

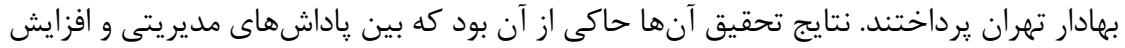

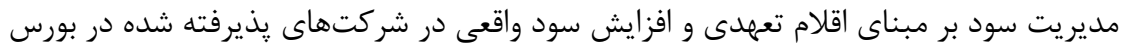
رابطه معنادارى وجود دارد.

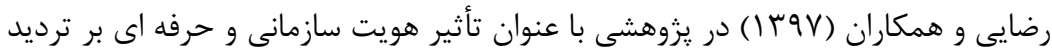

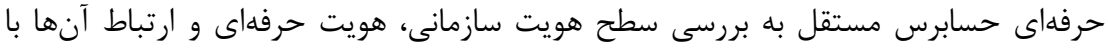

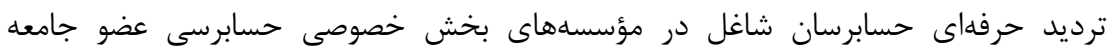

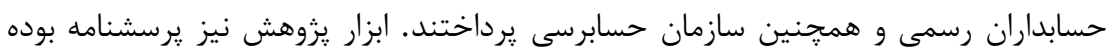

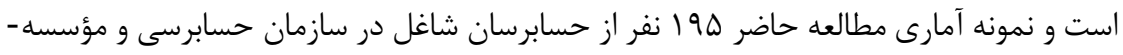
هاى بخش خصوصى حسابرسى بوده و فرضيههاى يزوهش نيز بر اساس معادلات ساختارى مورد 
آزمون قرار كرفت. نتايج يزوهش داد هويت سازمانى و هويت حرفهاى تأثير معنادار و مثبت بر بر برد

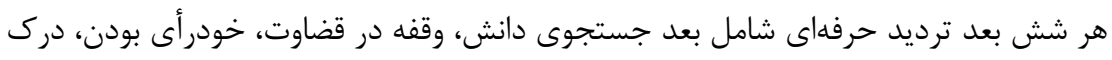

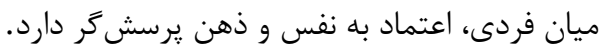

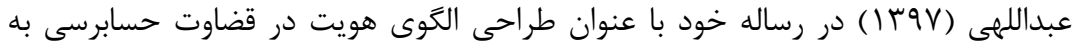

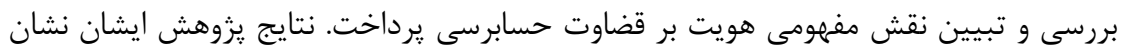

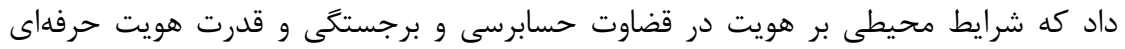

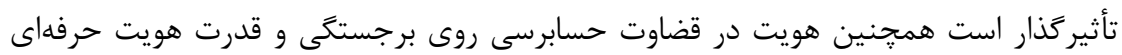
تأثير كذار است.

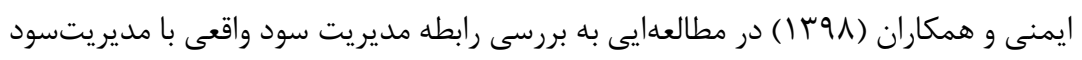

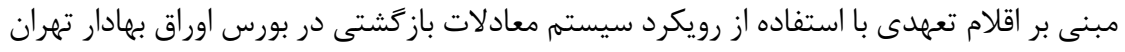

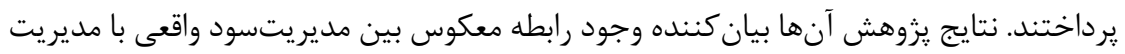

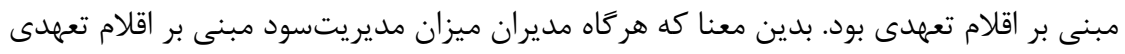
را افزايش (كاهش) دهند، دستكارى فعاليتهاى واقعى بلطور غيرمنتظرهايى كاهش (افزايش) خواهد يافت.

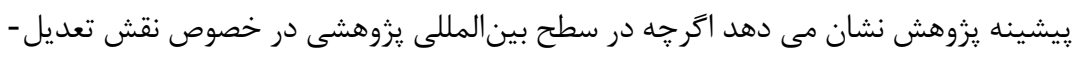

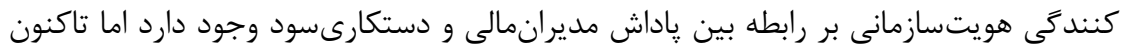

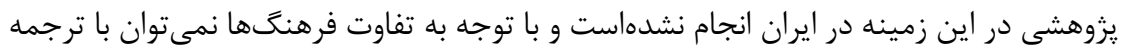

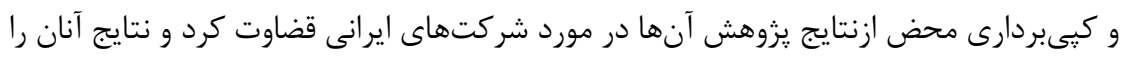

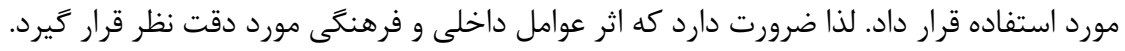

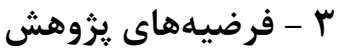

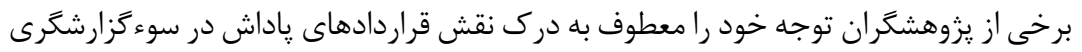

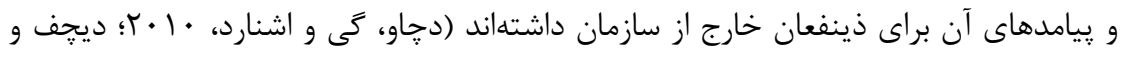

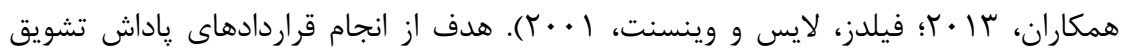

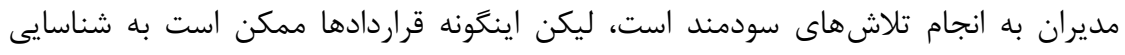

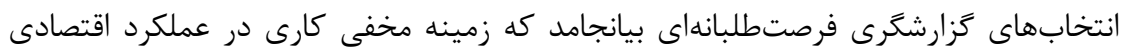

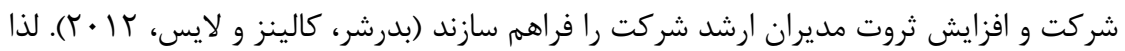

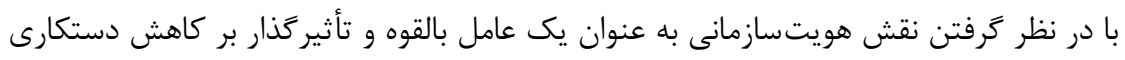

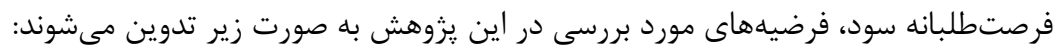

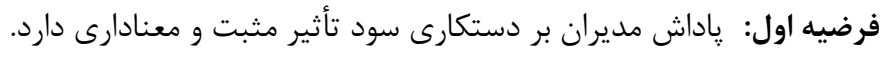


فرضيه دوم: هويت سازمانى بر دستكارى سود تأثير منفى و معنادارى دارد.

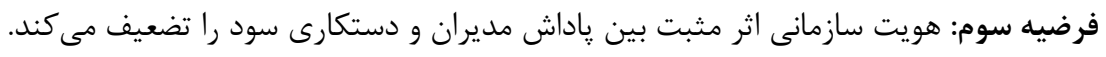

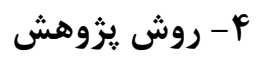

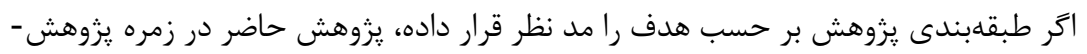

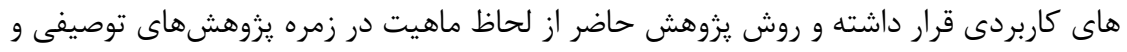

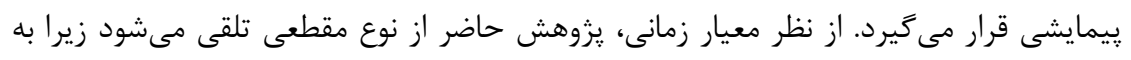

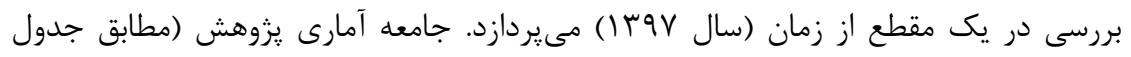

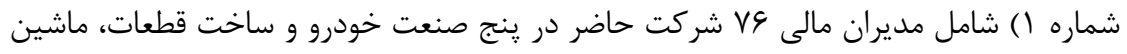

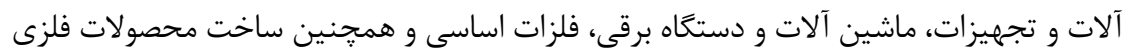

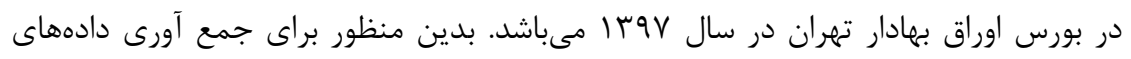

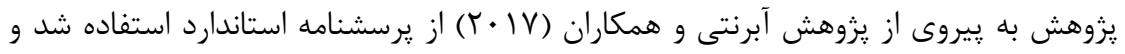

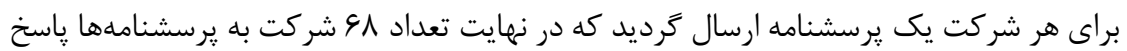

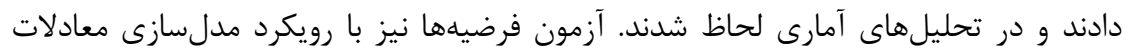

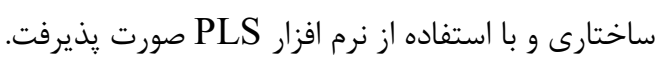

جدول (1)- جامعه آمارى يزوهش

\begin{tabular}{|c|c|}
\hline تعداد شركت & نام صنعت \\
\hline ro & خودرو و ساخت قطعات \\
\hline 14 & ماشينآلات و تجهيزات \\
\hline$\wedge$ & ماشين آلات و دستخاه برقى \\
\hline 19 & فلزات اساسى \\
\hline $1 \cdot$ & ساخت محصولات فلزى \\
\hline Vq & جمع كل \\
\hline
\end{tabular}

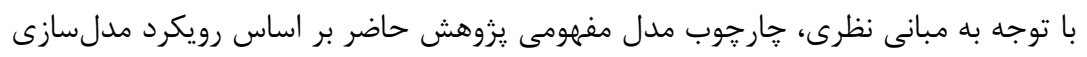

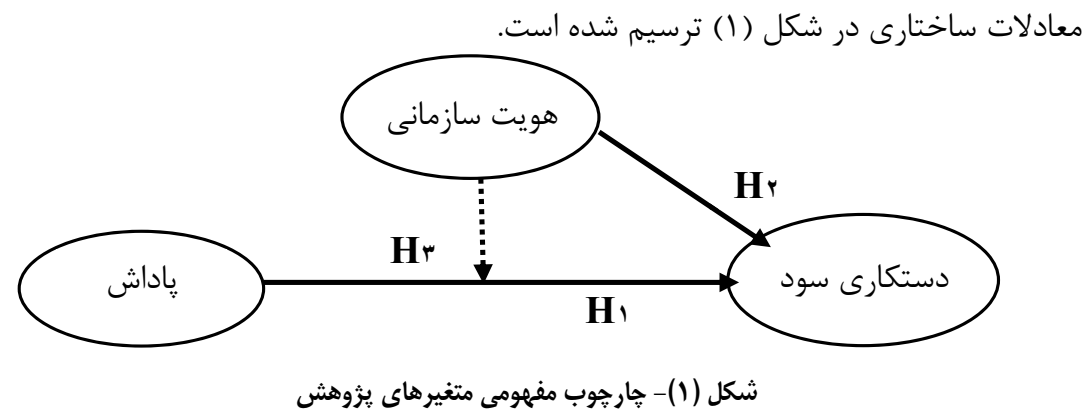


متغيرهاى مورد استفاده در اين يزوهش به شرح زير مىباشند: الف- متغير وابسته

دستكارى سود: با استفاده از يرسشنامه استاندارد كه توسط مرجنت (· • (199)، معرفى شده است دادههاى مربوط به آن استخراج شد كه در ييوست آورده شده است. اين برسشنامه داراى سه گويه مىباشد كه با استفاده از طيف ليكرت ينج درجهايى از خيلى كم تا خيلى زياد اندازهزيرى مىشوند. ب- متغير مستقل ֶاداش: براى اين متغير طى سوالى جند گزينهاى كه در پييوست آورده شده است، از ياسخ دهندها در يرسشنامه خواسته شد كه ياداش مبتنى بر عملكرد خود رئ را اعلام نمايند (آبرنتى و

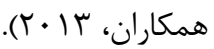
ج- متغير تعديل هويت سازمانى: از يرسشنامه استاندارد مائل و اشفورث (999 (1)، استفاده شد كه در پييوست

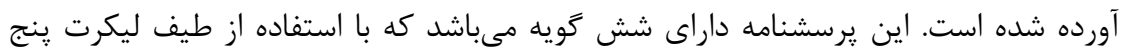

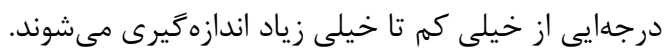

ه- يافتههاى يخوهش

به منظور آشنايى با خصوصيات نمونه آمارى، اطلاعات جمعيت شناسى يروهش در جدول (r) ارائه شده است. جدول (Y) - جمعيت شناختى يزوهش

\begin{tabular}{|c|c|c|c|}
\hline درصد & تعداد & متغير فرعى & متغير \\
\hline$\% 99$ & 90 & 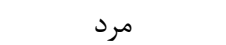 & \multirow{2}{*}{ جنسيت } \\
\hline$\%$ & r & زن & \\
\hline$\%$ & 10 & كمتر از • • سال & \multirow{3}{*}{ سن } \\
\hline$\% 4 q$ & 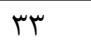 & بين •f تا •ه سال & \\
\hline$\%$ & $r \cdot$ & بيشتر از • له سال & \\
\hline (.9T & pr & كمتر از • r سال & \multirow{2}{*}{ سابقه كارى } \\
\hline$\%$ & ra & بيشتر از •r سال & \\
\hline
\end{tabular}

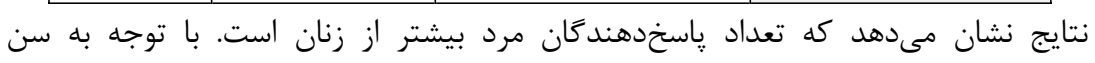

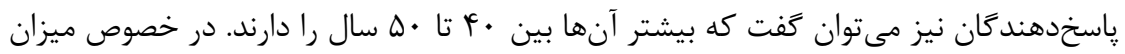

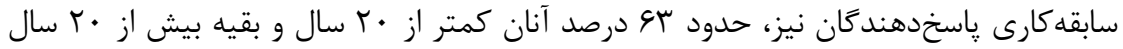
سابقه دارند. 


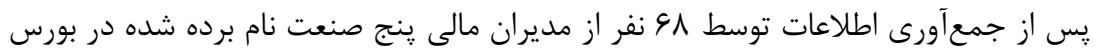

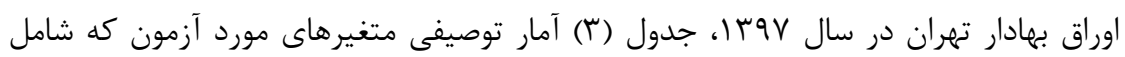

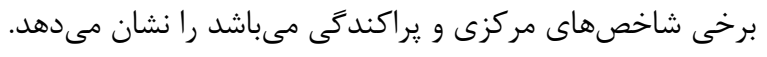

\begin{tabular}{|c|c|c|c|c|c|c|}
\hline & & & & & & \\
\hline & & & & & & \\
\hline & & & & & & \\
\hline •/999 & T/GKT & $\Delta / \cdot \cdot$ & $1 / \cdots$ & $9 \Lambda$ & Ol & هويتسازمانى \\
\hline $1 / \cdot \Delta q$ & $T / V Q$. & $\Delta / \cdot \cdot$ & $1 / \cdots$ & $9 \Lambda$ & PM & نستكارى سود \\
\hline
\end{tabular}

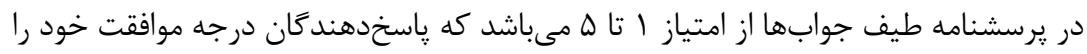

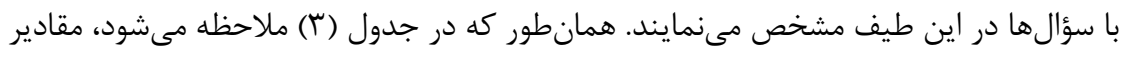

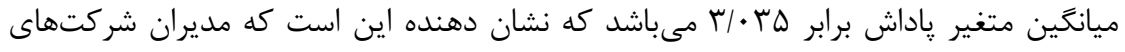

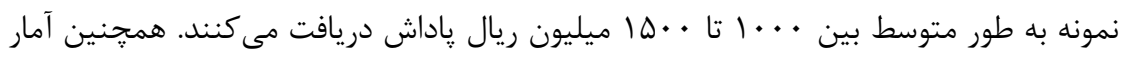

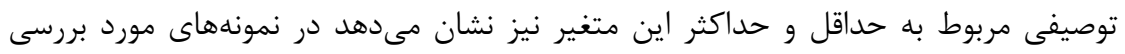

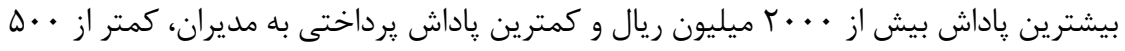
ميليون ريال مىباشد.

\section{برازش مدلهاى اندازهَيرى}

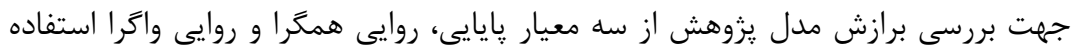

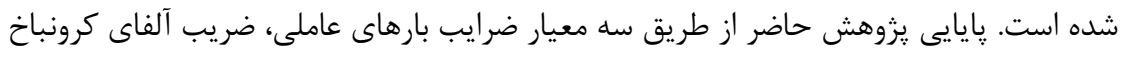
و وايايى تركيبى بررسى شده است.

ضر ايب بارهاى عاملى يزوهش بإي

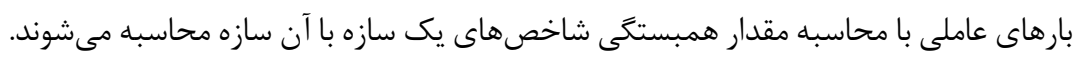

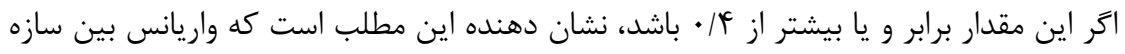

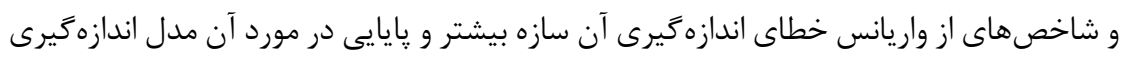

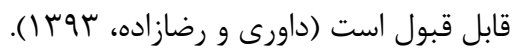

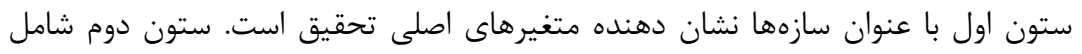

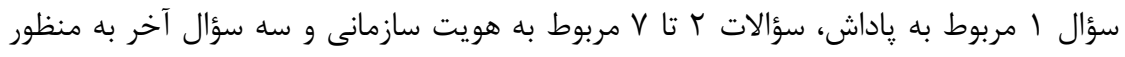

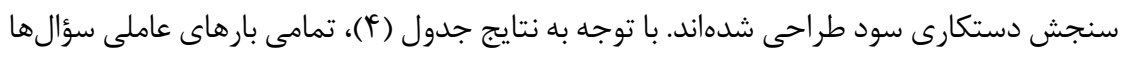

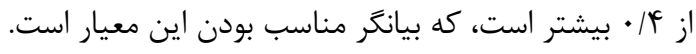




\begin{tabular}{|c|c|c|c|c|}
\hline نتيجه & مقداربحر انى & بار عاملى & سؤالات & سازهها \\
\hline عدم رد & $\cdot / f$ & $1 / \cdots$ & سؤال 1 & ل \\
\hline عدم رد & $\cdot / F$ & $\cdot \mid \Lambda V T$ & سؤال r & \multirow{6}{*}{ هويت سازمانى } \\
\hline عدم رد & $\cdot / f$ & $.194 \lambda$ & سؤال r & \\
\hline عدم رد & $\cdot / 4$ &.$/ 94 \wedge$ & سؤال † & \\
\hline عدم رد & $\cdot / f$ & - IAVT & سؤال هـ & \\
\hline عدم رد & $\cdot / f$ & .1994 & سؤال & \\
\hline عدم رد & $\cdot / f$ & $\cdot / V \Delta S$ & سؤال V V & \\
\hline عدم رد & $\cdot / f$ &.$/ 9 F F$ & سؤال 1 & \multirow{3}{*}{ دستكارى سود } \\
\hline عدم رد & $\cdot / 4$ & .1990 & سؤال 9 & \\
\hline عدم رد & $\cdot / 4$ &.$/ 9 T V$ & سؤال • 1 & \\
\hline
\end{tabular}

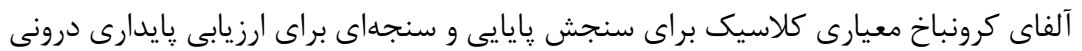

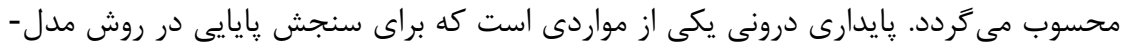

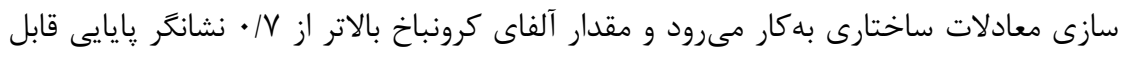

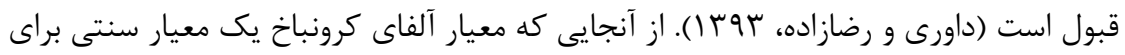

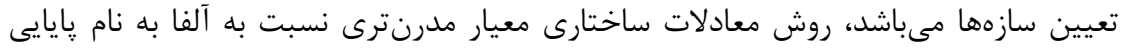

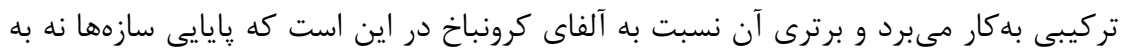

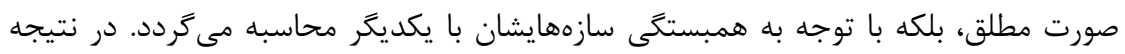

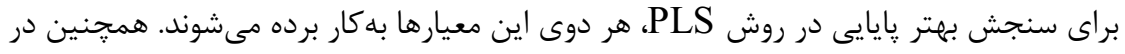

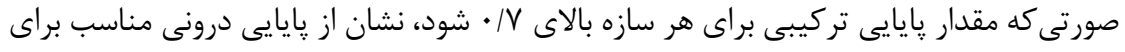

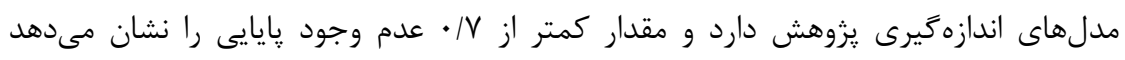

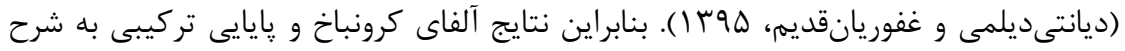

$$
\text { جدول (ه) مى باشد. }
$$

جدول (ه) - نتايج آزمون پايايى تركيبى و آلفاى كرونباخ

\begin{tabular}{|c|c|c|c|c|}
\hline نتيجه & مقدار بحرانى & آلفاى كرونباخ & پايايىتركيبى & \\
\hline عدم رد & $\cdot / \mathrm{V}$ & $\cdot|\wedge \Delta|$ &.$/ 991$ & هويت سازمانى \\
\hline عدم رد & $\cdot / \mathrm{V}$ & $\cdot|\lambda F|$ & - MAgT & دستكارى سود \\
\hline
\end{tabular}




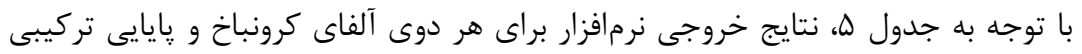

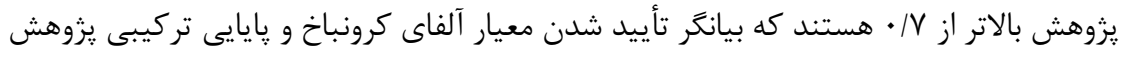

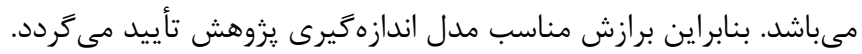

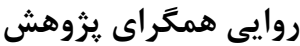

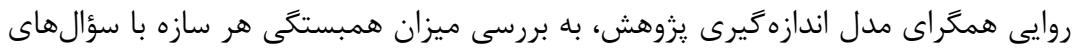

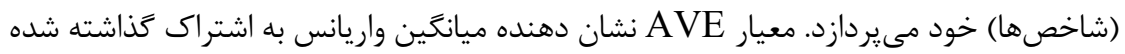

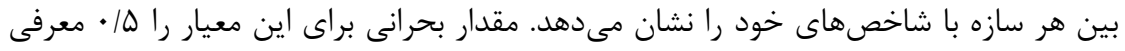

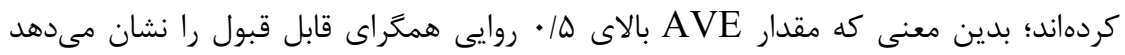

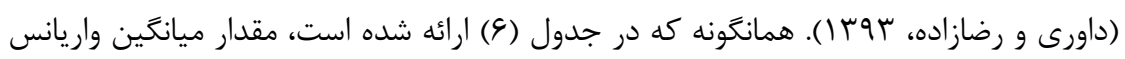

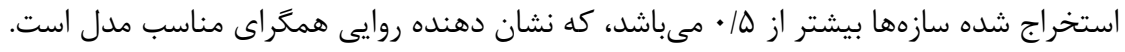

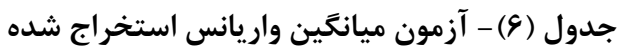

\begin{tabular}{|c|c|c|c|}
\hline نتيجه & مقدار بحرانى & AVE & \\
\hline عدم رد & $\cdot / 0$ & $1 / \cdots$ & لياداش \\
\hline عدم رد & $\cdot / \Delta$ & $\cdot \mid A \cdot \psi$ & هويت سازمانى \\
\hline عدم رد & $\cdot 10$ & .1194 & دستكارى سود \\
\hline
\end{tabular}

روايى واتر اي يزوهش

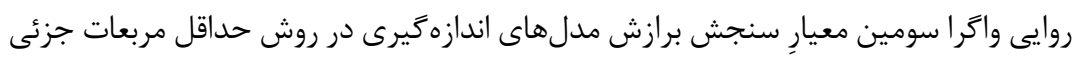

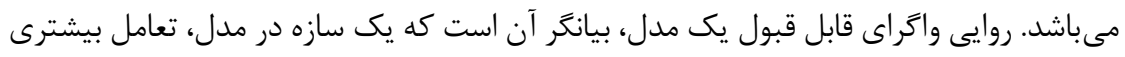

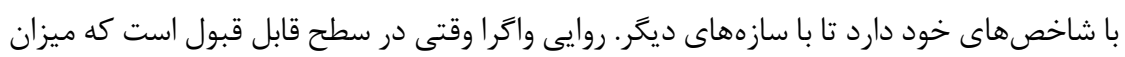

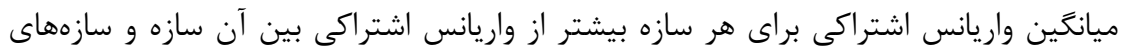

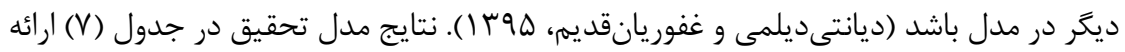
شده است.

جدول (V) - ماتريس سنجش روايى واكرا به روش فورنل و لاركر

\begin{tabular}{|c|c|c|c|}
\hline لياداش & دستكارى سود & هويت سازمانى & \\
\hline & & /ภ१V & هويت سازمانى \\
\hline & .1948 & $\cdot / T V A$ & دستكارى سود \\
\hline $1 / \cdots$ & .1110 & $-\cdot|\cdot| 4 \mid$ & يَاداش \\
\hline
\end{tabular}

همانطور كه در جدول (V) مشاهده مى گردد، مقدار جذر ميانگين مقادير اشتراكي تمام سازه-

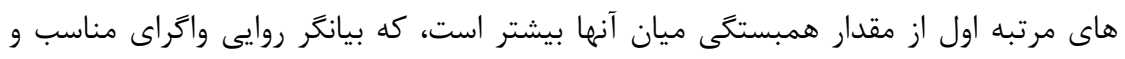


برازش خوب مدلهاى اندازمخيرى تحقيق را نشان مى دهد. همجنين، نتايج حاكى از آن است كه

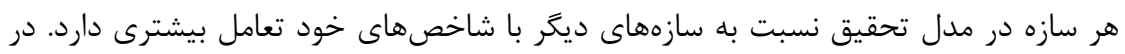

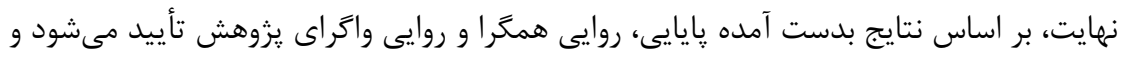

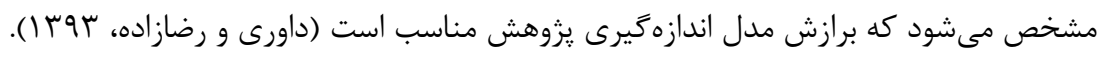

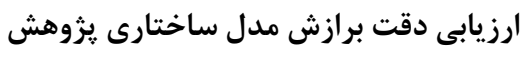

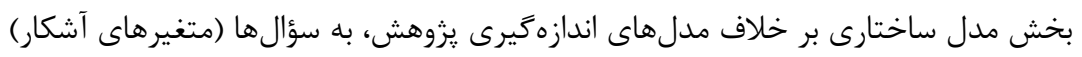

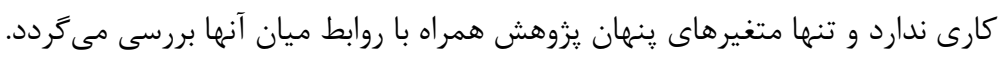

\section{معيار R Squares}

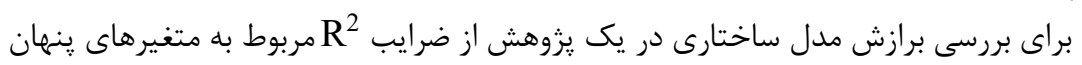

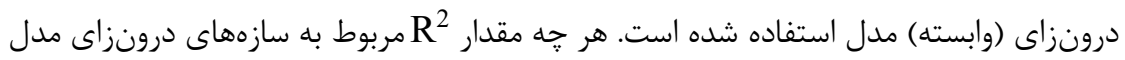

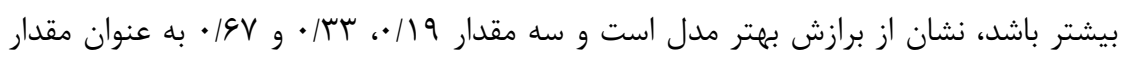

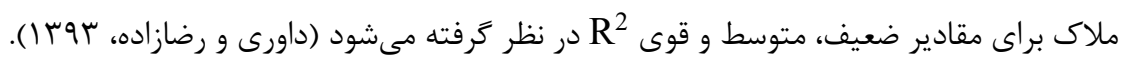

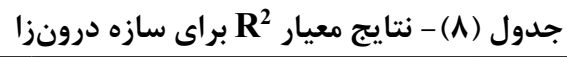

\begin{tabular}{|c|c|c|c|}
\hline نتيجه & ميزان برازش & $\mathrm{R}^{2}$ & متغير درونزا \\
\hline عدم رد & متوسط & ת ז & دستكارى سود \\
\hline
\end{tabular}

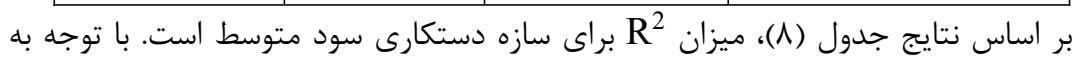

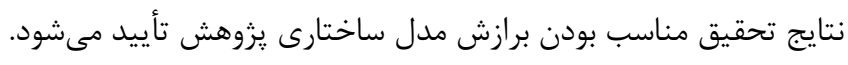

\section{معيار}

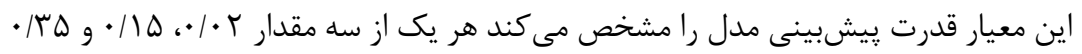

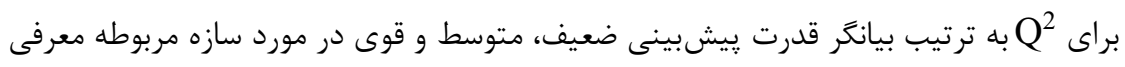

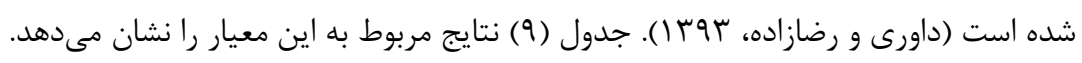
Qدول (9) - نتايج معيار (9) نتايج مرطول

\begin{tabular}{|c|c|c|}
\hline قدرت بيشبينى & Q مقدار Q & متغير \\
\hline متوسط & . YA9 & دستكارى سود \\
\hline
\end{tabular}

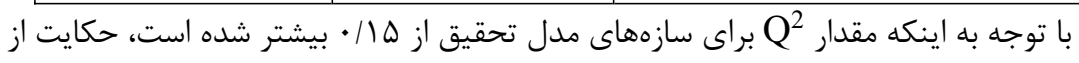
آن دارد كه قدرت ييشبينى مدل متوسط است و برازش مناسب مدل ساختارى تحقيق را رأئيد مىنمايد. 


\section{برازش مدل كلى}

مدل كلى يزوهش شامل هر دو بخش مدل اندل اندازمخيرى و ساختارى مىشود و با تأييد برازش

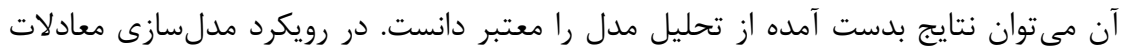

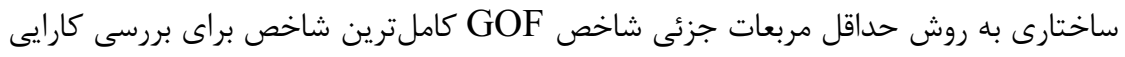

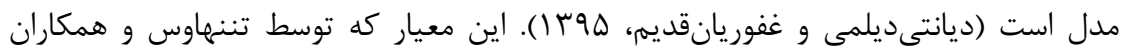

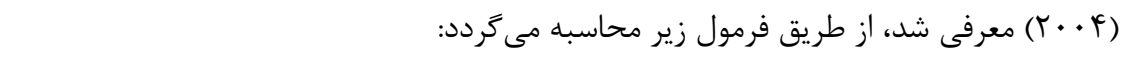
$G O F=\sqrt{\overline{\text { communalities }} \times \overline{R^{2}}}$

$$
\text { كه در آن: }
$$

ضريب تمينين

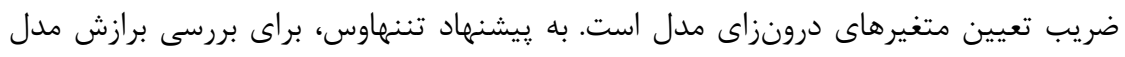

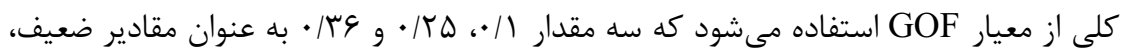

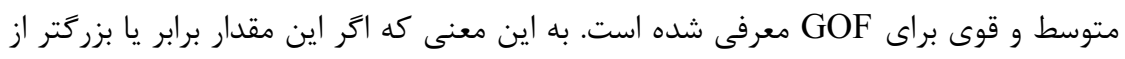

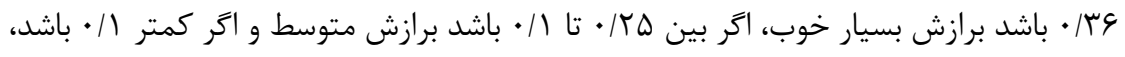

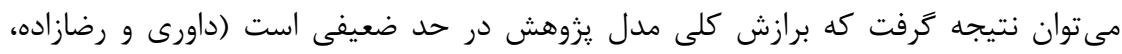

\begin{tabular}{|c|c|c|c|}
\hline $\mathrm{R}^{2}$ & Communality & نماد & متغيرهاى مكنون \\
\hline$\cdot \cdots$ & $1 / \cdots$ & RE & باداش \\
\hline$\cdot \%$ & $\cdot / A \cdot 4$ & OI & هويت سازمانى \\
\hline 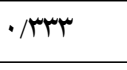 & - / A9F & PM & دستكارى سود \\
\hline \multicolumn{4}{|c|}{ جدول (1) - نتايج برازش مدل كلى } \\
\hline \multicolumn{2}{|c|}{ GOF } & $\overline{\mathrm{R} 2}$ & $\overline{\text { Communalıty }}$ \\
\hline.$/ D F V$ & \multicolumn{2}{|c|}{ זחות/. } & $\cdot / 199$ \\
\hline
\end{tabular}

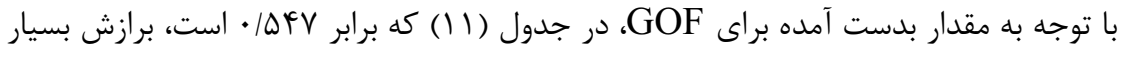
مناسب مدل را نشان مى دهد.

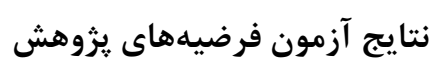

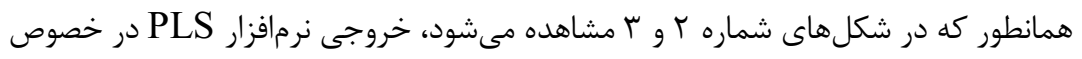

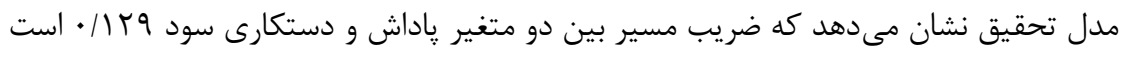

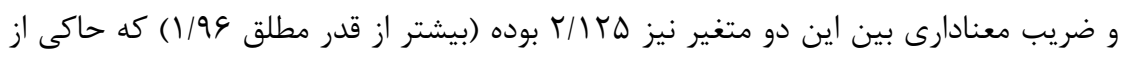




$$
\begin{aligned}
& \text { آن است كه تأثير متغير پاداش بر دستكارى سود مثبت و معنى دار است. بنابراين طبق نتايج }
\end{aligned}
$$

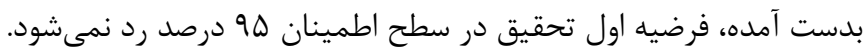

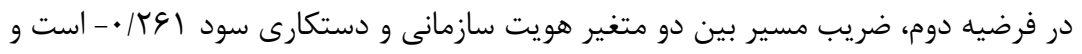

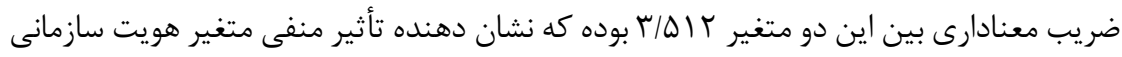

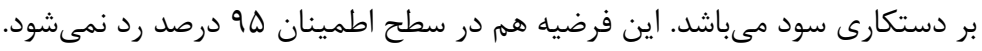

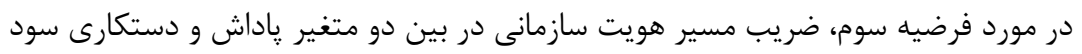

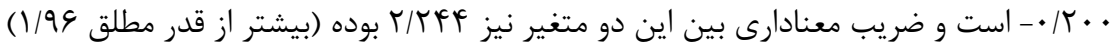

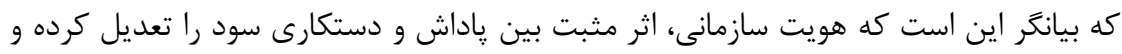

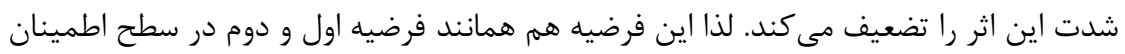

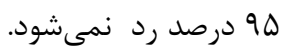

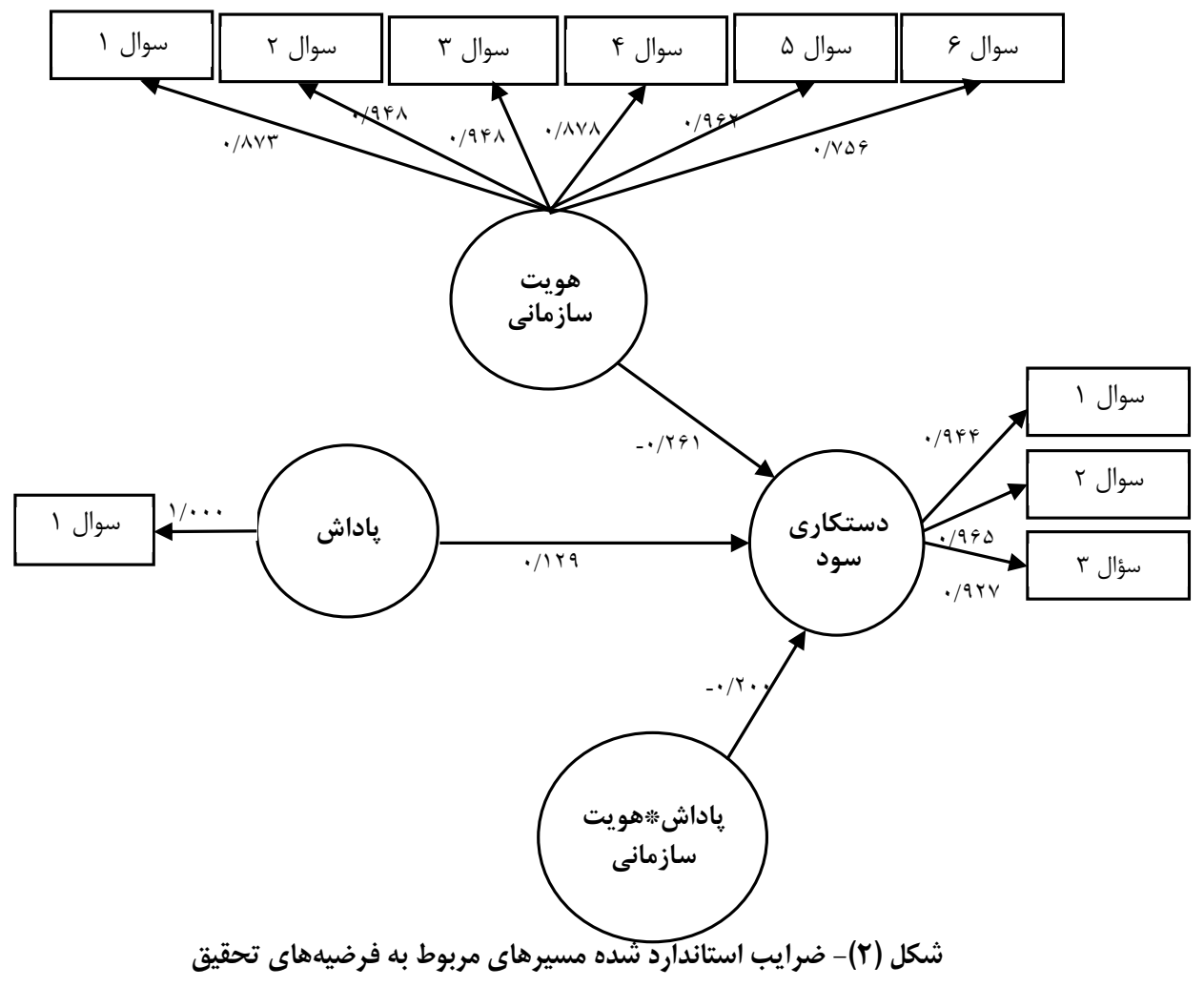


شكل (ץ) - مقادير t-values مربوط به فرضيههاى تحقيق

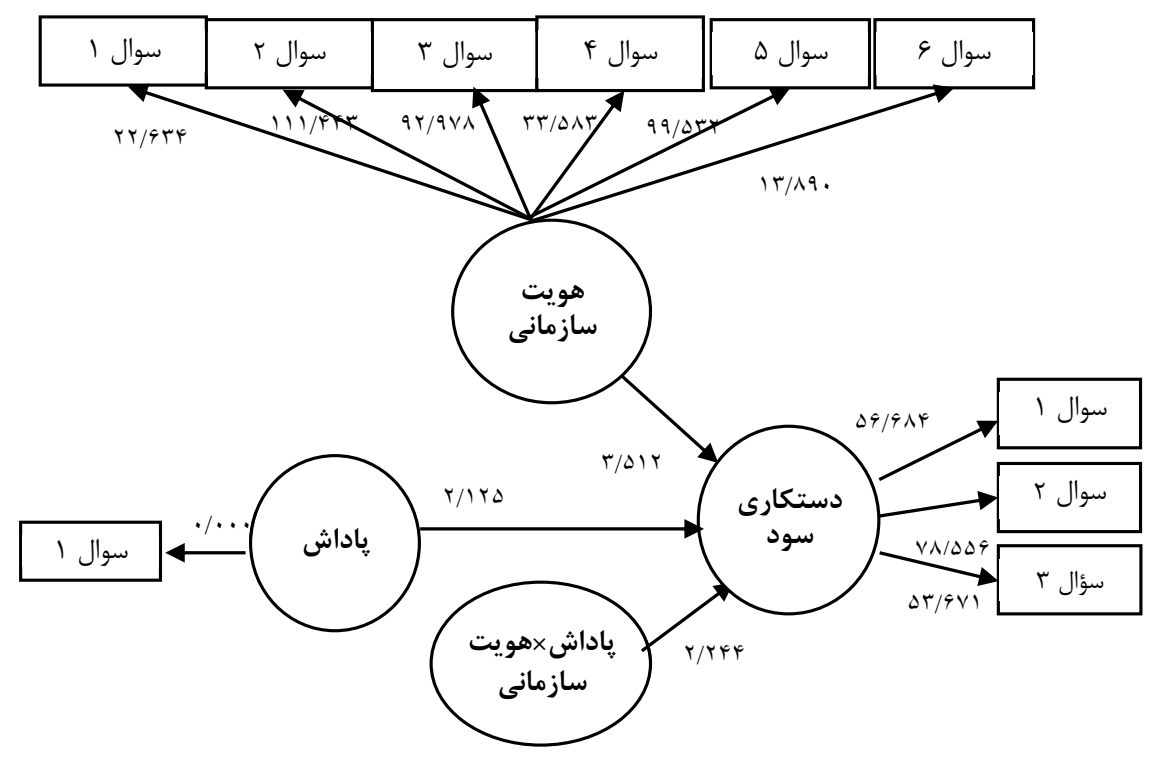

جدول (r) - نتايج مربوط به آزمون فرضيههاى بزوهش

\begin{tabular}{|c|c|c|c|c|c|}
\hline |آزمون & 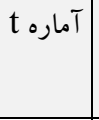 & ضريب & 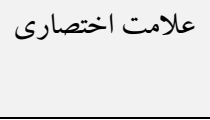 & مسير & فرضيه \\
\hline عدم رد & $r / T$ ro &.$/ 1 \mathrm{ra}$ & $\mathrm{RE} \rightarrow \mathrm{ME}$ & لِاداش † ستكارى سود & 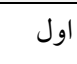 \\
\hline | عدم رد & $r / \Delta \mid r$ & $-\cdot / Y 4 \mid$ & $\mathrm{OI} \rightarrow \mathrm{ME}$ & هويت سازمانى † دستكارى سود & 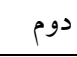 \\
\hline | ع عدم رد & Y/YKF & $-\cdot / 4 \cdot \cdot$ & $\mathrm{OI} * \mathrm{RE} \rightarrow \mathrm{ME}$ & |هويت سازمانى × باداش † دستكارى سود & 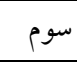 \\
\hline
\end{tabular}

همجنين در جدول (r) (I) بطور خلاصه نتايج مربوط به آزمون فرضيههاى يزوهش ارائه شدهاست.

7- نتيجل

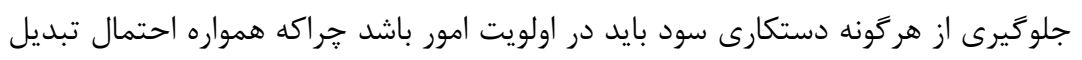

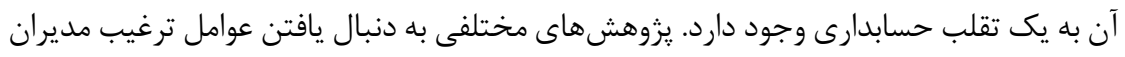

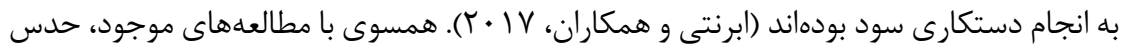

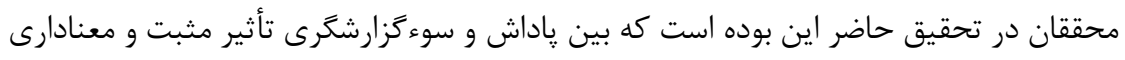

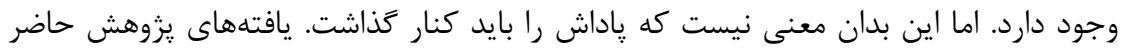

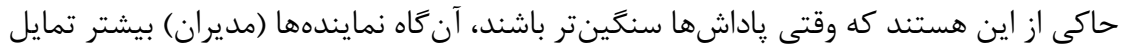


به سوءززارشكرى دارند. اما همه آنها اقدام به انجام اينكار نمى كنند. يرواضح است كه عوامل

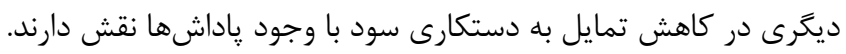

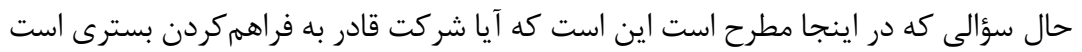

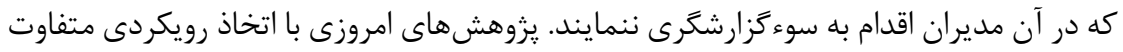

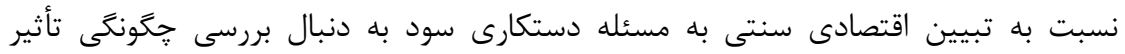

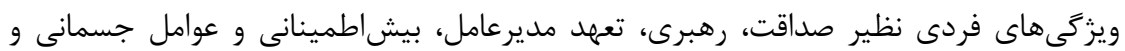

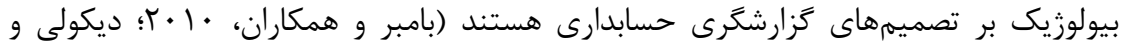

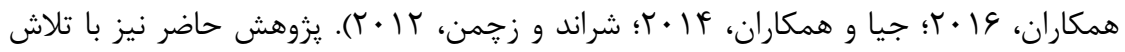

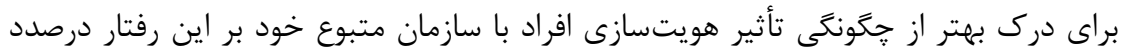

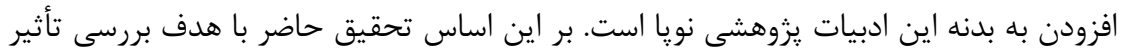

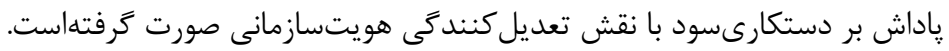

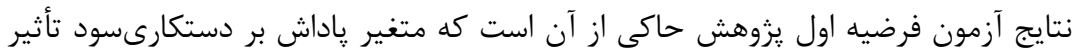

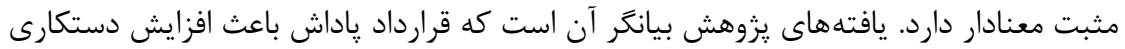

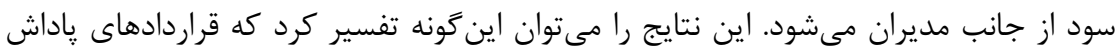

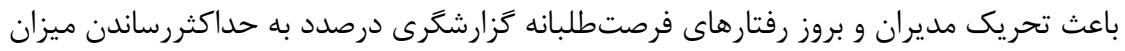

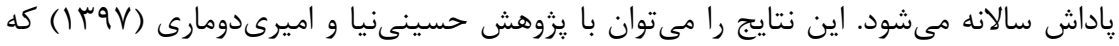

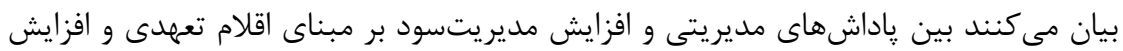

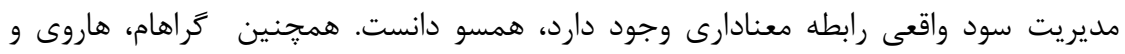

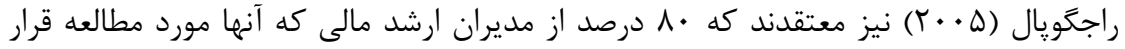

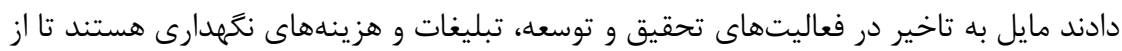

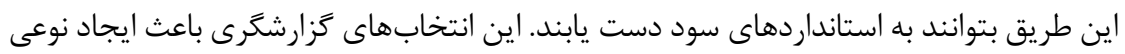

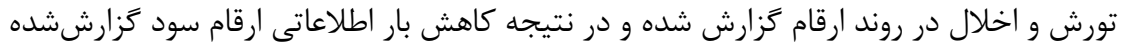

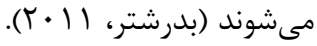

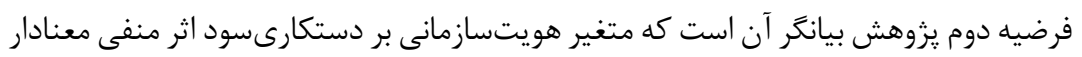

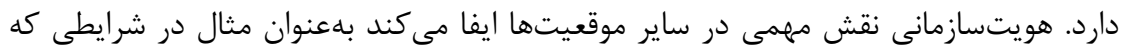

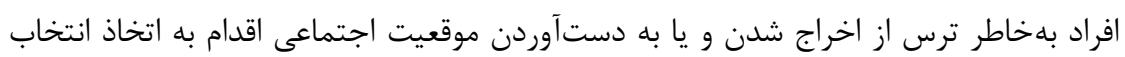

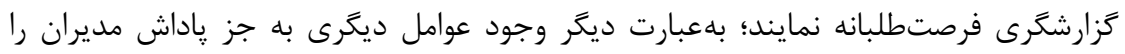

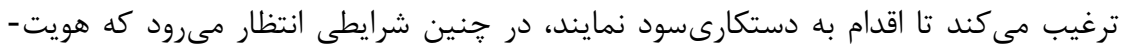

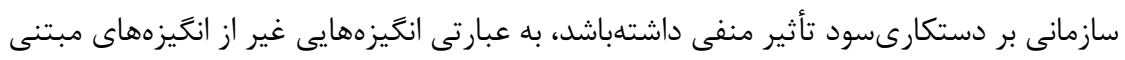


بر ياداش براى تعيين دستكارىسود وجود دارد كه نقش هويتسازمانى ممانعت از بروز جنين

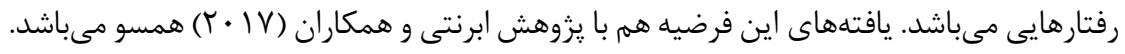

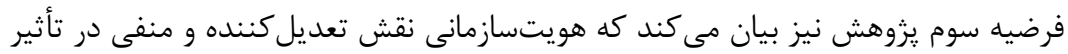

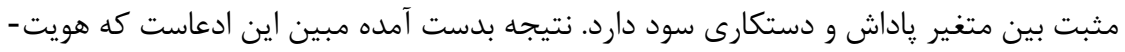

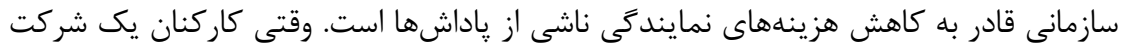

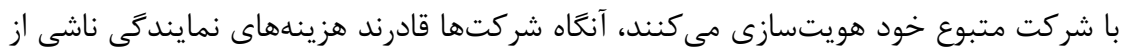

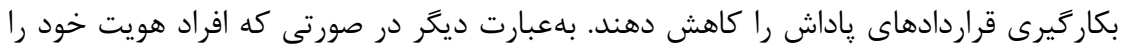

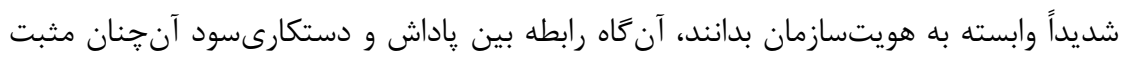

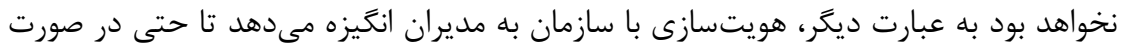

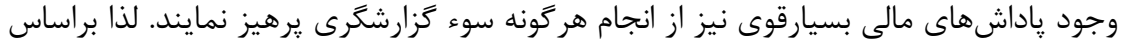

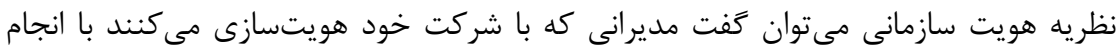

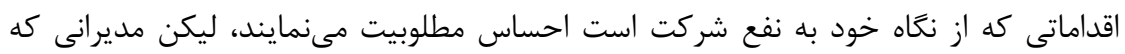

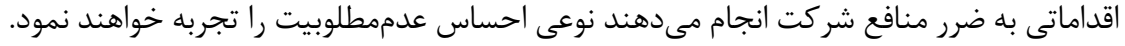

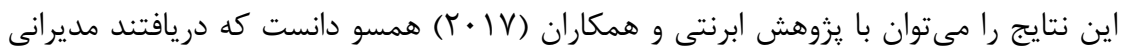

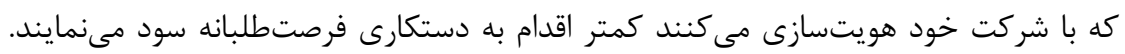

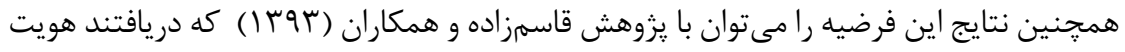

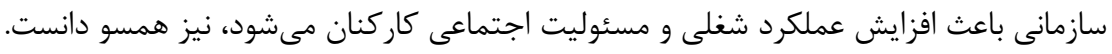

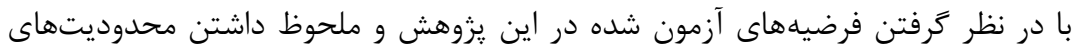
تحقيق مىتوان ييشنهادهاى كاربردى به شرح زير بيان نمود:

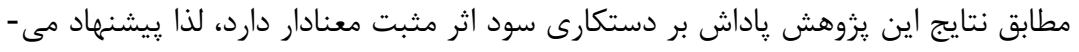

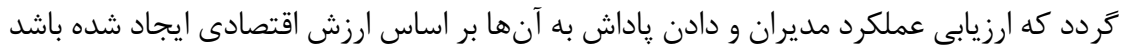

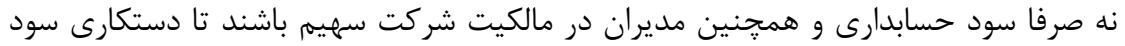

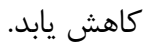
مطابق با نتايج اين يزوهش هويتسازمانى بر دستكارىسود اثر منفى معنادار دارد، در واقع

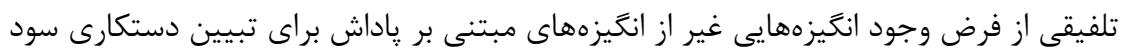

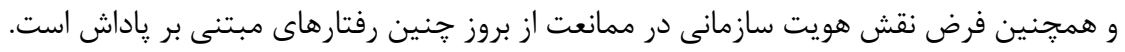

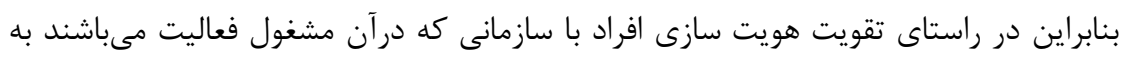

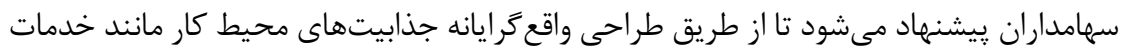

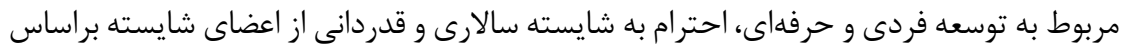

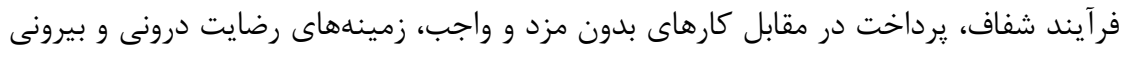


اعضاء را فراهم آورند، زيرا باتوجه به اين عوامل خواهند توانست زمينههاى دلبستكى افراد به

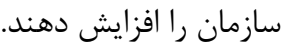

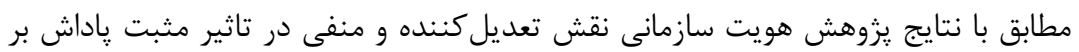

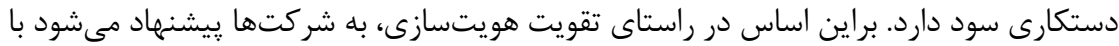

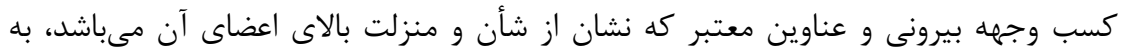

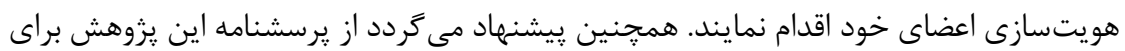
كزينش بهتر براى استخدام مديران مالى استفاده نمايند.

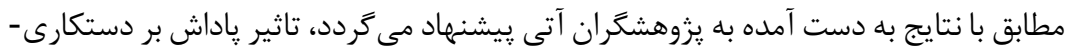

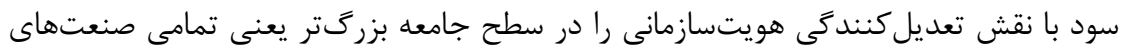
بورس اوراقبهادار تهران را مورد مطالعه قراردهند. علاوه بر اين تأثير هويتسازمانى بر ساير

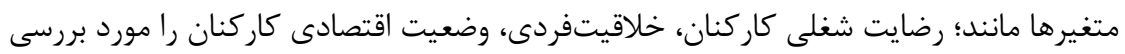

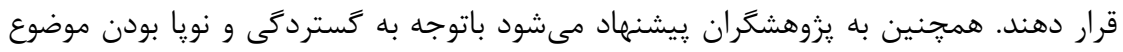

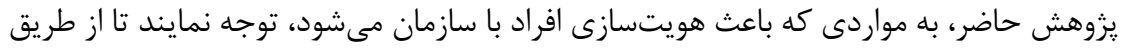

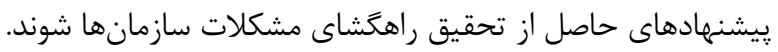

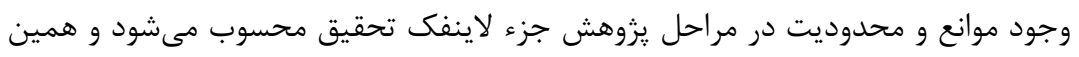

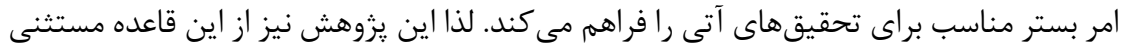

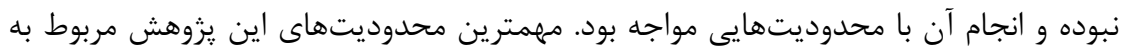

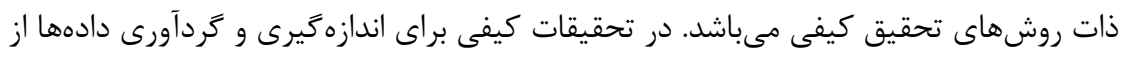

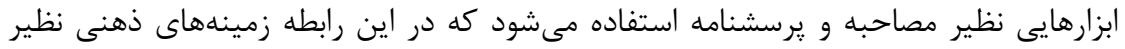

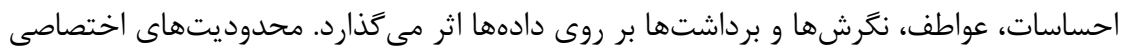

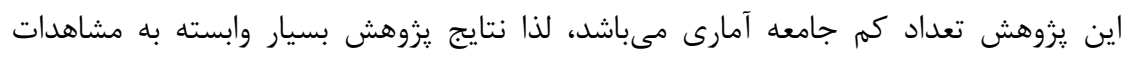

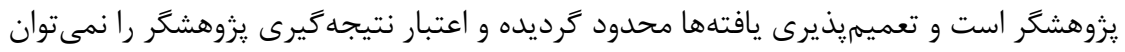

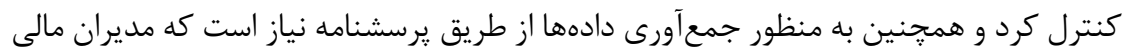

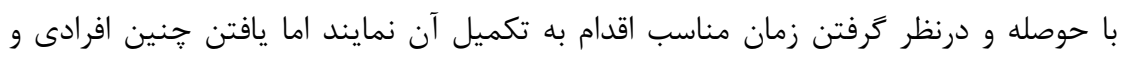

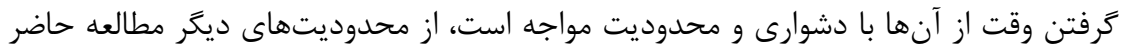

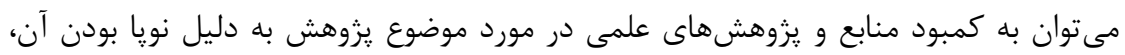

V - Vقدير، تشكر و ملاحظات اخلاقى - V

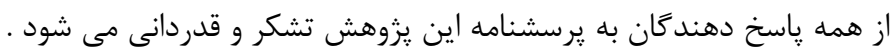




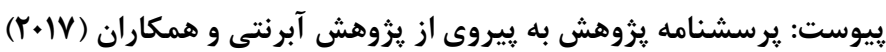

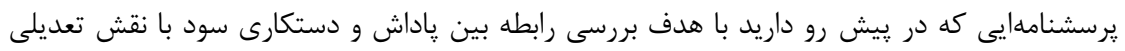

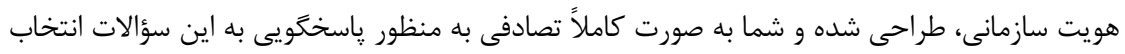

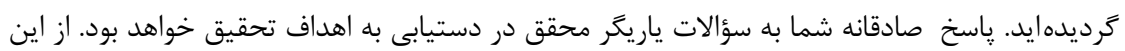

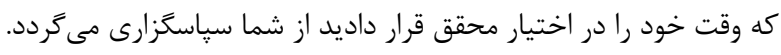

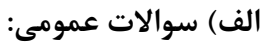

جنس: مرده

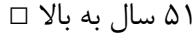
$\square$ سال $\Delta \cdot-|+|$

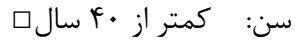

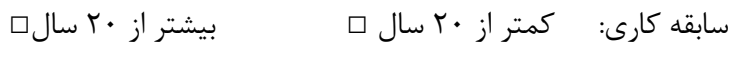

ب) سوالات تخصصى:

\begin{tabular}{|c|c|c|c|c|c|c|c|}
\hline \multicolumn{5}{|c|}{ ميزان موافقت } & \multirow[b]{2}{*}{ كويلها } & \multirow[b]{2}{*}{$\hat{3}$} & \multirow[b]{2}{*}{$\underset{3}{3}$} \\
\hline $\begin{array}{l}3 \\
3 \\
3 \\
3\end{array}$ & ?" & $\begin{array}{l}3 \\
3 \\
3 \\
-1\end{array}$ & $y_{2}$ & $\begin{array}{l}-1 \\
z_{2}\end{array}$ & & & \\
\hline$\Delta$ & f & $r$ & $r$ & 1 & آتى به دوره جارى متبوع با تعويق مخارج ضمايد. & 1 & 3 \\
\hline$\Delta$ & f & r & $r$ & 1 & آتى به دوره جارى متبوع با تسريع دمايد. روند فروش اقدام به انتقال سودهاى & r & $\frac{3}{3}$ \\
\hline$\Delta$ & r & $r$ & $r$ & 1 & |ز واحد متبوع با انتقال وجوه نقد در بين حسابها در صد صد اجتناب & $r$ & 3 \\
\hline$\Delta$ & f & $r$ & $r$ & 1 & زمجيد مىنمايده فردى از سازمان من به نيكى ياد مى كند، كويى از من & 1 & \\
\hline$\Delta$ & f & $r$ & $r$ & 1 & 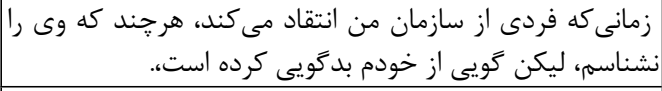 & r & g \\
\hline$\Delta$ & r & r & $r$ & 1 & علاقه وافرى به اطلاع از نظرات ديخران درباره سازمانم دارم. & r & : \\
\hline$\Delta$ & r & r & r & 1 & |آنها《، از ضمير درباره سازمانم صحبت استفاده مى منمايمه، به جاى استفاده از ضمير & r & $\stackrel{3}{9}$ \\
\hline$\Delta$ & f & r & r & 1 & 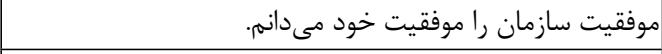 & $\Delta$ & \\
\hline$\Delta$ & r & r & r & 1 & 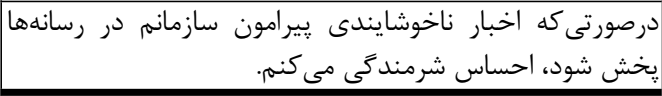 & 4 & \\
\hline 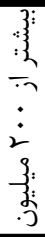 & $\begin{array}{l}\dot{3} \\
\dot{3} \\
\dot{2} \\
\dot{3} \\
3 \\
3\end{array}$ & 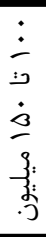 & 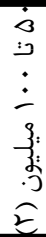 & 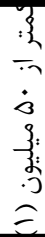 & ياداش مبتنى بر عملكرد خود را اعلام نماييد. (تومان) & 1 & $\frac{3}{43}$ \\
\hline
\end{tabular}


اسكندرلى، طاهر و بخشنده، عبدالخليل. (و9 (1). بررسى اثر فرصت رشد بر رابطه بين پاداش

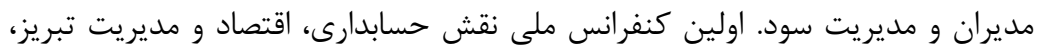

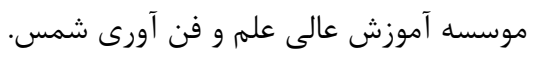

ايمنى، محسن؛ رهنماى روديشتى، فريدون؛ بنى مهيد، بهمن. (

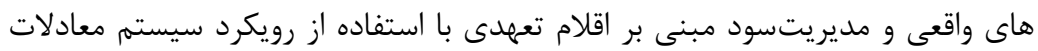

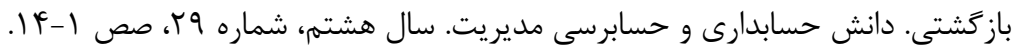

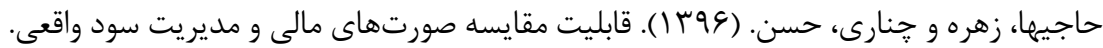

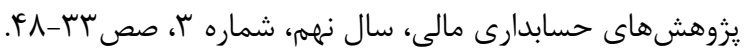

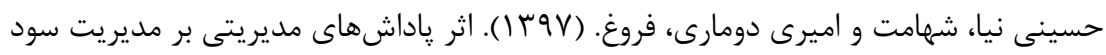

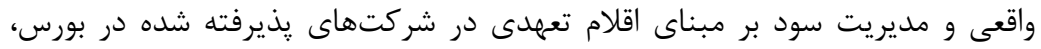

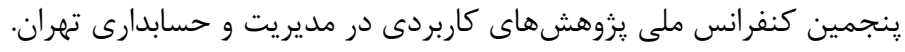

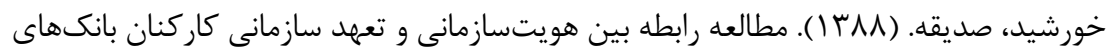

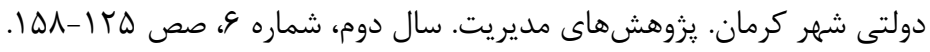

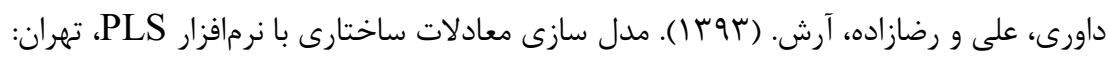

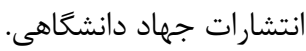

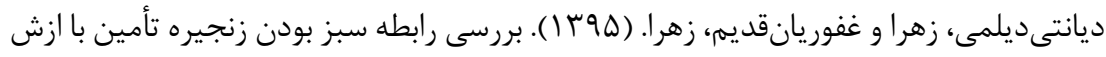

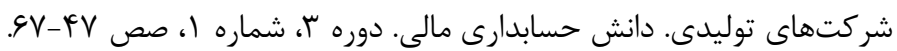

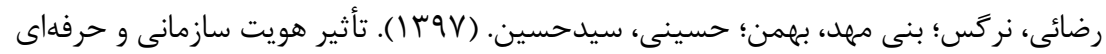

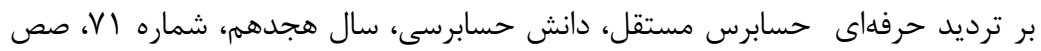
. 199-IVD

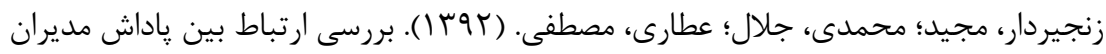

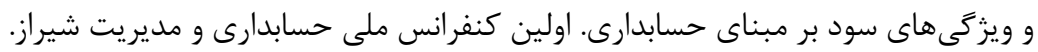

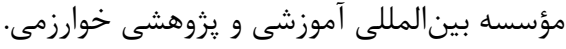

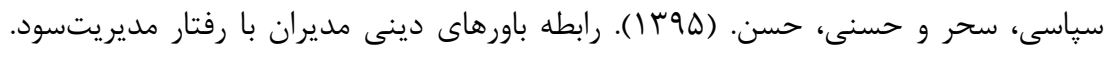

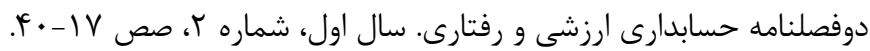

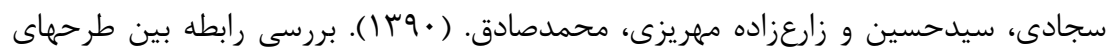

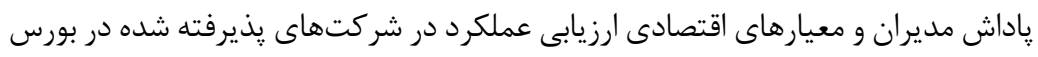

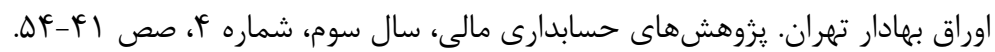




$$
\begin{aligned}
& \text { عبداللهى، احمد. (1) (1). طراحى الكَى هويت در قضاوت حسابرسى. رساله دكترى حسابدارى } \\
& \text { دانشكاه علامه طباطبايى تهران. }
\end{aligned}
$$

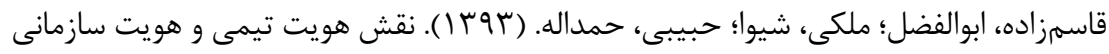

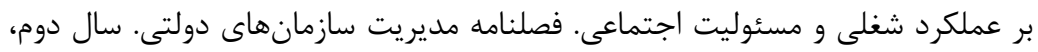

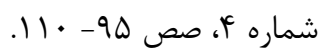

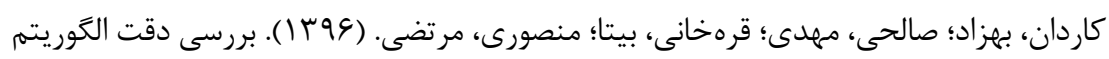

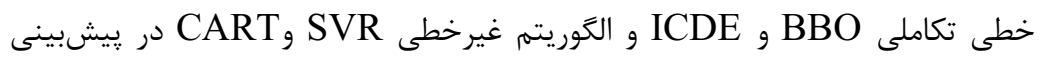

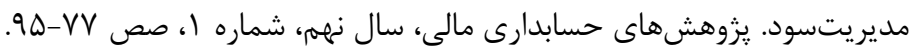

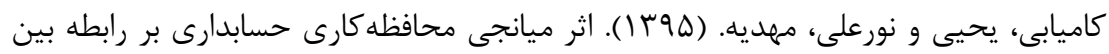

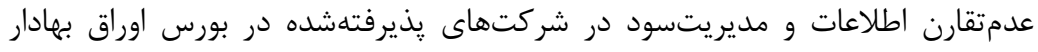

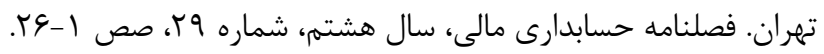

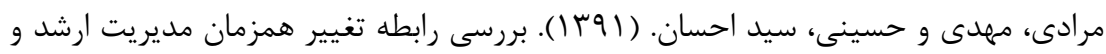

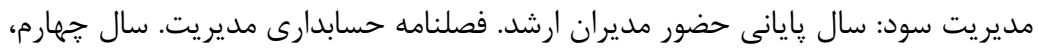

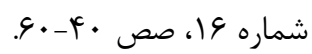

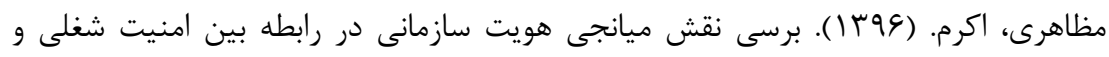

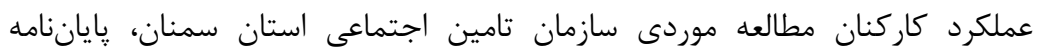

$$
\begin{aligned}
& \text { كارشناسى ارشد دانشخاه ازاد اسلامى شاهرود. }
\end{aligned}
$$

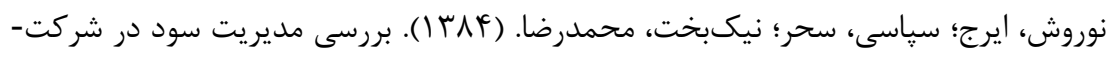

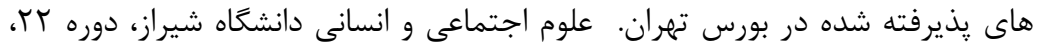

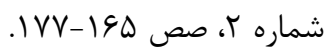

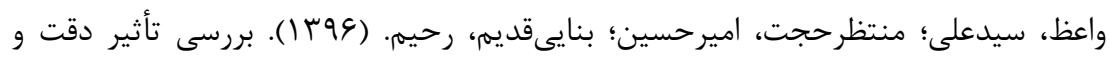

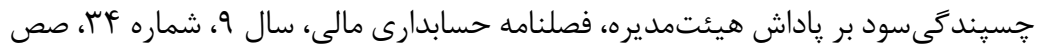

$$
.1 Y \wedge-10 \text {. }
$$

Abernethy, M. A., J. Bouwens, and P. Kroos. 2017. Organization Identity and Earnings Manipulation. Accounting, Organizations and Society 58: $1-14$.

Abernethy, M. A., J. Bouwens, and L. Van Lent. 2013. The role of performance Measures in the Intertemporal Decisions of Business Unit Managers. Contemporary Accounting Research 30 (3): 925-961.

Aboody, D., and R. Kasznik. 2000. CEO Stock Option Awards and the Timing of Corporate Voluntary Disclosures. Journal of Accounting and Economics 29 (1): 73-100. 
Adler, P. S., and C. X. Chen. 2011. Combining Creativity and Control: Understanding Individual Motivation in large-scale Collaborative Creativity. Accounting, Organizations and Society 36 (1): 63-85.

Akerlof, G. A., and R. E. Kranton. 2000. Economics and Identity. The Quarterly Journal of Economics 115 (3): 715-753.

Akerlof, G. A., and R. E. Kranton. 2008. Identity, Supervision, and Work Groups. American Economic Review 98 (2): 212-217.

Armstrong, C. S., A. D. Jagolinzer, and D. F. Larcker. 2010. Chief Executive Officer Equity Incentives and Accounting Irregularities. Journal of Accounting Research 48 (2): 225-271.

Bamber, L. S., J. Jiang, and I. Y. Wang. 2010. What is my style? The Influence of Top Managers on Voluntary Corporate Financial disclosure. The Accounting Review 85 (4): 1131-1162.

Badertscher, B. A., D. W. Collins, and T. Z. Lys. 2012. Discretionary accounting choices and the predictive ability of accruals with respect to future cash flows. Journal of Accounting and Economics 53 (1): 330 352.

Badertscher, B. A. 2011. Overvaluation and the choice of alternative earnings management mechanisms. The Accounting Review 86 (5): 1491-1518.

Benabou, R., and J. Tirole. 2016. Bonus Culture: Competitive pay, Screening, and multitasking. Journal of Political Economy 124 (2): 305370 .

Bergstresser, D., and T. Philippon. 2006. CEO Incentives and Earnings Management. Journal of Financial Economics 80 (3): 511-529.

Bhojraj, S., P. Hribar, M. Picconi, and J. McInnis. 2009. Making Sense of Cents: An examination of Firms that Marginally Miss or Beat Analyst Forecasts. The Journal of Finance 64 (5): 2361-2388.

Boivie, S., D. Lange, M. L. McDonald, and J. D. Westphal. 2011. Me or we: The effects of CEO Organizational Identity on Agency costs. Academy of Management Journal 54 (3): 551-576.

Bouaziz, D., B. Salhi, and A. Jarboui. 2020. CEO characteristics and earnings management: empirical evidence from France. Journal of Financial Reporting and Accounting ahead-of-print. https://doi.org/10.1108/JFRA-01-2019-0008

Broberg, P., T. Umans, P. Skog, and E. Theodorsson. 2018. Auditors'professional and organizational identities and commercialization in audit firms. Accounting, Auditing \& Accountability Journal 31 (2): 374-399.

Dechow, P. M., and D. J. Skinner. 2000. Earnings management: Reconciling the views of Accounting Academics, practitioners, and Regulators. Accounting Horizons 14 (2): 235-250. 
Deci, E. L. 1971. Effects of Externally Mediated Rewards on Intrinsic Motivation. Journal of Personality and Social Psychology 18 (1): 105115.

Dichev, I. D., J. R. Graham, C. R. Harvey, and S. Rajgopal. 2013. Earnings quality: Evidence from the Field. Journal of Accounting and Economics $56(2): 1-33$.

Dikolli, S., T. Keusch, W. J. Mayew, and T. D. Steffen. 2016. A Linguisticbased Approach to Measuring Innate Executive Traits: The Case of CEO Integrity. Working paper, Duke University, INSEAD and Yale University.

Dukerich, J. M., B. R. Golden, and S. M. Shortell. 2002. Beauty is in the Eye of Thebeholder: The Impact of Organization Identity, and Image on the Cooperative Behaviors of Physicians. Administrative Science Quarterly 47 (3): 507-533.

Dutton, J. E., J. M. Dukerich, and C. V. Harquail. 1994. Organizational Images and member Identity. Administrative Science Quarterly 39 (2): 239-263.

Feng, M., W. Ge, S. Luo, and T. Shevlin. 2011. Why do CFOs Become Involved Immaterial Earnings Managements? Journal of Accounting and Economics 51 (1): 21-36.

Fields, T. D., T. Z. Lys, and L. Vincent. 2001. Empirical research on accounting choice. Journal of Accounting and Economics 31 (1): 255307.

Garcia-Falieres, A., and O. Herrbach. 2015. Organizational and Professional Identification in Audit Firms: An Affect Approach. Journal of Business Ethics 132 (4): 753-763.

Ge, W., D. Matsumoto, and J. L. Zhang. 2011. Do CFOs have Style? An Empirical investigation of the Effect of Individual CFOs on Accounting practices. Contemporary Accounting Research 28 (4): 1141-1179.

Geiger, M. A., and D. S. North. 2006. Does Hiring a New CFO Change Things? An investigation of Changes in Discretionary Accruals. The Accounting Review 81 (4): 781-809.

Graham, J. R., C. R. Harvey, and S. Rajgopal. 2005. The Economic Implications of Corporate Financial Reporting. Journal of Accounting and Economics 40 (1): 3-73.

Guidry, F., A. J. Leone, and S. Rock. 1999. Earnings-based Bonus Plans and Earnings Management by Business-unit Managers. Journal of Accounting and Economics 26 (1-3): 113-142.

Healy, P. M. 1985. The Effect of Bonus Schemes on Accounting Decisions. Journal of Accounting and Economics 7 (1-3): 85-107.

Heinle, M. S., C. Hofmann, and A. H. Kunz. 2012. Identity, Incentives and the Value of Information. The Accounting Review 87 (4): 1309-1334. 
دو فصلنامه حسابدارى ارزشى و رفتارى، سال ينجم، شماره دهم، پإييز و زمستان وجسا

r.

Jensen, M. C., and K. J. Murphy. 2012. The Earnings Management Game: It's Time to stop it. Working paper, Harvard Business School and University of Southern California.

Li, V. 2019. The Effect of Real Earnings Management on the persistence and Informativeness of Earnings. The British Accounting Review 51 (4): 402-423.

Mael, F., and B. E. Ashforth. 1992. Alumni and their alma mater: A partial Test of the Reformulated Model of organizational Identity. Journal of Organization Behavior 13 (2): 103-123.

Mazar, N., O. Amir, and D. Ariely. 2008. The Dishonesty of Honest people: A Theory Ofself-Concept Maintenance. Journal of Marketing Research 45 (6): 633-644.

Merchant, K. A. 1990. The Effects of Financial Controls on Data Manipulation and Management Myopia. Accounting Organizations and Society 15 (4): 297-313.

Kesen, M. 2016. Linking Organizational Identification with IndividualCreativity: Organizational Citizenship. Journal of Yasar University 11 (41): 56-66.

Roychowdhury, S. 2006. Earnings Management through Real Activities Manipulation. Journal of Accounting and Economics 42 (3): 335-370

Schrand, C., and S. Zechman. 2012. Executive Overconfidence and the Slippery Slope to Fraud. Journal of Accounting and Economics 53 (12): 311-329.

Tajfel, H., and J. C. Turner. 1979. An Integrative Theory of Intergroup Conflict. In W. G. Austin, \& S. Worchel (Eds.). The Social psychology of Intergroup Relations (pp. 33-47) California: Brooks \& Cole.

Tenenhaus, M., S. Amato, and V. Esposito. 2004. A global goodness-of-fit index for PLS structural equation modelling. In: Proceedings of the XLII SIS scientific meeting: 739-742.

Tourky, M., P. Kitchen, and A. shaalan. 2019. The role of corporate identity in CSR implementation: An integrative framework. Journal of Business Research In Press. https://doi.Org/10.1016/j. jbusres.2019.02.046 